\title{
The Material Soul: Strategies for Naturalising the Soul in an Early Modern Epicurean Context
}

\author{
Charles T. Wolfe (Centre for History of Science, Dept. of Philosophy and \\ Moral Sciences, Ghent University)
}

Michaela van Esveld (Unit for History and Philosophy of Science, University of Sydney)

In Conjunctions: Body, Mind and Spirit from Plato to Descartes, ed. Danijela Kambaskovic-Sawers (Springer, forthcoming)

\begin{abstract}
We usually portray the early modern period as one characterised by the 'birth of subjectivity' with Luther and Descartes as two alternate representatives of this radical break with the past, each ushering in the new era in which ' $\mathrm{I}$ ' am the locus of judgements about the world. A sub-narrative called 'the mindbody problem' recounts how Cartesian dualism, responding to the new promise of a mechanistic science of nature, "split off" the world of the soul/mind/self from the world of extended, physical substance - a split which has preoccupied the philosophy of mind up until the present day. We would like to call attention to a different constellation of texts - neither a robust 'tradition' nor an isolated 'episode', somewhere in between - which have in common their indebtedness to, and promotion of an embodied, Epicurean approach to the soul. These texts follow the evocative hint given in Lucretius' De rerum natura that 'the soul is to the body as scent is to incense' (in an anonymous early modern French version). They neither assert the autonomy of the soul, nor the dualism of body and soul, nor again a sheer physicalism in which 'intentional' properties are reduced to the basic properties of matter. Rather, to borrow the title of one of these treatises (L'âme matérielle), they seek to articulate the concept of a material soul. We reconstruct the intellectual development of a corporeal, mortal and ultimately material soul, in between medicine, natural philosophy and metaphysics, including discussions of Malebranche and Willis, but focusing primarily on texts including the 1675 Discours anatomiques by the Epicurean physician Guillaume Lamy; the anonymous manuscript from circa 1725 entitled L'âme matérielle, which is essentially a compendium of texts from the later seventeenth century (Malebranche, Bayle) along with excerpts from Lucretius; and materialist writings such Julien Offray de La Mettrie's L'Homme-Machine (1748), in order to articulate this concept of a 'material soul' with its implications for notions of embodiment, materialism and selfhood.
\end{abstract}


"Material": "composed of matter. The soul of animals is material, that of humans is spiritual." (Furetière) ${ }^{1}$

“The soul is to the body as scent is to incense." (L'âme matérielle) ${ }^{2}$

\section{Introduction}

2. Early conceptions of the organic soul

3. The interpenetration of medicine and metaphysics: models for the material soul

4. The anatomy of brutes and the corporeal soul: Willis

5. Resources for a psychophysiology: Malebranche

6. The material soul as "purest fire" and "subtle wind": Lamy

7. L'âme matérielle

8. Materialism and the soul's remainder: La Mettrie and Diderot

9. Conclusion

\section{Introduction}

In the radical streams of early modern thought, from 'anatomicalmetaphysical' treatises such as the Epicurean physician Guillaume Lamy's Discours anatomiques, clandestine manuscripts such as L'Âme matérielle, and, some generations later, La Mettrie's L'Homme-Machine, we find a unique intellectual situation in which materialism is asserted while the existence of the soul is not denied. At first glance this may seem contradictory: isn't one of the key tenets of materialism the denial of the soul in favour of the sole existence of the body (or the brain)? In fact, as readers familiar with Lucretius and Epicurus and their early modern posterity already know, there is a intermediate, or perhaps we should say hybrid option, in which the immortal, or purely intellective soul is denied, but a material soul is affirmed. And indeed, it was an old idea. The thesis of the materiality of the soul is considered to be a characteristic materialist tenet well before the thesis of the eternity of matter and motion (Mothu 1990-1991) or the inherence of motion

\footnotetext{
${ }^{1}$ Furetière 1702, p. 518. Unless otherwise indicated all translations are ours.

${ }^{2}$ L'Âme matérielle, 2003, p. 174.
} 
in matter, with Toland. Thus the Abbé Pluquet, in his eighteenth-century catalogue of heresies - which, like other works by anti-materialist clerics (apologeticists), always proves to be a helpful guide to the internal structures of heterodox thought - explains that the thinkers he calls "Materialists or Materials" (Matérialistes ou Matériels, terminology he attributes to Tertullian) believe "that the soul is born of matter." 3

This concept is sometimes presented as deriving from medicine (Thomson 2008) or from theological debate (Henry 1989, Kors 1990), and of course texts such as the revealingly titled Religio medici by Thomas Browne (on the religious side) and Guillaume Lamy's Discours anatomiques (on the atheistic side) fuse medical and theological discourses together. The physician's knowledge of the structure of the body can be presented as a posteriori knowledge of design - something Harvey and to a lesser extent Willis do, and Boyle did much more emphatically, particularly in his 1688 Disquisition about the Final Causes of Natural Things, in which he takes Harvey's discovery of the circulation of the blood to be evidence of design, and presents Harvey himself as supporting this view. ${ }^{4}$ But the physician's knowledge of the body can also support the claim that there is no immortal soul (Lamy, L'âme matérielle, La Mettrie); there may exist a material soul, that dies with us, as doctors claim to have observed. Of course, depending on their own ideological convictions, physicians can either claim that on the Last Judgment we are resurrected as a whole (body and soul) or, in proper Lucretian fashion, that we need have no fear because afterwards there is nothing.

It is important to note that the very existence of such a concept as the material soul - in its different contexts, registers and intentions - challenges received notions of both materialism and the history of psychological concepts such as intentionality. Consider the following verdict on materialism, in a discussion of eighteenth-century French thought:

\footnotetext{
3 Pluquet 1762/1788, II, s.v. “Matérialistes," p. 300.

4 "I remember that when I asked our famous Harvey ... what were the things that induced him to think of a circulation of the Blood? He answered me, that when he took notice that the valves in the veins of so many several parts of the body, were so placed that they gave free passage to the blood towards the heart, but opposed the passage of the venal blood the contrary way: he was invited to imagine, that so provident a cause as nature had not plac'd so many valves without design. . .." (Boyle, Disquisition about the Final Causes of Natural Things, in Boyle 1772/1968, vol. V, p. 427; emphasis ours). But Boyle also warns against taking final causes to be more primary than natural science: "the naturalist should not suffer the search, or the discovery of a Final Cause of Nature's works, to make him under-value or neglect the studious indagation [investigation] of their efficient causes" (ibid., p. 411).
} 
Materialism as a working philosophy, used as a tool in the scientific investigation of the material universe, is appropriate and highly effective. Intended for the objective analysis and description of the world of externals, it yields disastrous results when applied to the inner, subjective world of human nature, human thought, and human emotions. ${ }^{5}$

Our response is not strictly that it yields, or yielded only the best results, but that the world of subjectivity, of inner principles of animation and desire, is far from being either a polar opposite of what the materialist project seeks to grasp, or somehow categorically out of its reach. ${ }^{6}$

In what follows we reconstruct the conceptual persona of the 'material soul' in the early modern period. There are many materialist concepts of 'mind' (as locus of mental activity), in which the soul can be presented as integrated within an embodied, material whole - whether in the metaphysical context of a 'functional dualism' (Wright 2000), the medicalised approach to types of soul (corporeal, incorporeal, etc.) or the more naturalistic context of soul as the product of the brain. Descartes is often granted a paradigmatic status in these debates, as having articulated a conception of body-soul relations that played a defining role in his time (also because his delimitation allows - up to a point - for the safe pursuit of medicine and natural philosophy, as distinct from the metaphysics of substance dualism). But as our discussion shows (see also Wright 1991a), he was not so paradigmatic: either because of a more pronounced Epicurean dimension of the debates (to which the concept of material soul in large part belongs), or because postCartesians such as Regius, Boerhaave and Gaub are actually quite far removed from either Cartesian mechanism and/ or Cartesian physiology. ${ }^{7} \mathrm{~A}$ somewhat different point, discussed in sections 5 and 7 , is the usage of Malebranche's account of brain and animal spirits - itself an extension of Cartesian themes, but an original one - in a materialist direction.

One major objection to the materiality of the soul, which forms an alternate line of development, concerns its mortality or immortality (and its materiality or immateriality, which were often run together with the former distinction). At least as early as Locke in the late seventeenth century (himself

\footnotetext{
${ }^{5}$ Hill 1968, p. 90.

${ }^{6}$ For a related opposition between a more 'static' picture of early modern materialism and one which emphasises its fluid, humoral, dynamic character see Sutton and Tribble's critique of Hawkes (forthcoming).

${ }^{7}$ In addition, figures at the intersection of medicine and metaphysics like Francis Glisson (Henry 1987) effectively do not belong to any of these 'traditions' or 'trajectories'. That Descartes has come to be understood in much more 'embodied' terms in recent years does not affect the story told in this paper (see Sutton 1998, Wolfe 2012a, 2012b).
} 
perhaps influenced by earlier Puritans such as Richard Baxter ${ }^{8}$ ), and extending as far as Priestley in the late eighteenth century, the case was clearly and fluently made that one could be an observant and devout Christian without being committed to substance dualism (itself suspected of being a piece of Catholic metaphysics). These arguments about the divine superaddition of matter to thought combine sophisticated appeals to Scripture and a priori conceptual analysis of, e.g., thought and matter as substances. Thus Locke famously and influentially claimed that since we do not, and cannot know the essence of matter or thought, we cannot know with any certainty whether God ("Omnipotency") could give ("superadd") matter the power of thought": "he who will give himself leave to consider freely ... will scarce find his Reason able to determine him fixedly for, or against, the Soul's Materiality."10

But it was also possible to challenge this 'doxa' concerning the soul by appealing to a different source: an Epicurean, then humoral, then chimiatric and finally materialist tradition, from Epicurus and Lucretius to Robert Burton, Thomas Willis, Guillaume Lamy, the anonymous clandestine texts discussed here such as L'âme matérielle, and La Mettrie. Should one speak of a humoral materialism? ${ }^{11}$ An Epicurean tradition? The Epicurean concept of material soul - by which we mean an artefact of early modernity, not something found in the original Epicurean corpus, although some of its key components include citations of texts such as Lucretius' De rerum natura - is a combination of several elements, including:

- the notion of the organic soul, coming out of the naturalistic appropriation of Aristotle's De anima with Pomponazzi and others (to which specifically Epicurean elements are added);

- the corporeal soul in a 'neuropsychological' context, with Willis;

- Malebranche's post-Cartesian psychophysiology of animal spirits. We shall present the key features of these three elements ( $\S 2,4,5$ below), along with some reflections on how medicine and metaphysics are articulated in this process $(\S 3)$, before showing how they come together in two key texts of the early modern Epicurean tradition: the writings of the seventeenthcentury Epicurean physician Guillaume Lamy (§ 6), and the clandestine

\footnotetext{
${ }^{8}$ In his 1682 work Of the immortality of mans soule ..., Baxter challenged "the Cartesians" in the name of devotion to God, ironically "confessing" that he was "too dull to be sure that God cannot endue matter itself with the formal virtue of Perception" (cit. in Henry 1987, p. 36).

${ }^{9}$ Locke 1975, IV.iii.6, pp. 540-541.

${ }^{10}$ Ibid., p. 542.

${ }^{11}$ Some historians consider humoralism as "an alternative way to study the body" which allows for "a consideration of the 'lived' body" (Smith 2008, p. 473). We do not discuss this aspect here; see Wolfe 2012a.
} 
manuscript L'âme matérielle (§ 7). Then we turn, in § 8, to the explicitly materialist reception of these ideas in the mid-eighteenth century, before concluding (§9) with some reflections on models of the material soul and their implications for the history of materialism.

\section{Early conceptions of the organic soul}

Aristotle defines the soul as "the first actuality of a natural body which has organs" in book II of De anima (412 b 5-6). In the fourteenth and fifteenth centuries this supported a psychology that gave each activity of the soul both a psychological and physical explanation. ${ }^{12}$ For example, memory was defined as a capacity for recall but was also located in the vapours in the posterior ventricle of the brain. ${ }^{13}$ The way in which Aristotle's De anima was, in his own view, inscribed in a 'biological' project, continuous with his more explicitly biological works (on the parts, generation and movement of animals) has been increasingly recognised in recent scholarship (van der Eijk 2005). And the availability of this work for more heterodox projects of 'naturalisation' in early modernity is patent in the opening lines of the treatise: the "study of the soul" contributes greatly to the "study of nature" (De an., 402 a 5-6), because the soul is a "principle of life." This began with commentators on De anima and other writers in the Aristotelian tradition, who introduced arguments based on anatomical information into treatments of the organic soul (Park 1988). Further, in the part of Avicenna 's Shifâ' (published 1020-1027) which came to be viewed as a commentary on Aristotle's De anima during the later Middle Ages, we find a distinction drawn between the study of the soul in itself, which belongs to metaphysics, and the study of the soul as the principle of animation, which belongs to natural philosophy (Lagerlund 2004).

Overall, the initial naturalisation of the Aristotelian system took shape because natural philosophers did not restrict their analysis to the final and formal causes of psychological phenomena (the soul and its faculties), but also focused on efficient and material causes (perhaps primarily so), which they interpreted as the physical processes accounting for these phenomena and the organs in which they took place. ${ }^{14}$ This increasingly marked turn towards physiological organs was, unsurprisingly, presented as Aristotle's own view

\footnotetext{
12 Park 1988, Des Chene 2000.

13 Park 1988, p. 468.

14 Park 1988, p. 468; Rapp 2006.
} 
in each case, which begins to look rather forced once the organic soul is explicitly presented as material (it was already accepted by many to be extended and divisible), and identified with spiritus, the vapour refined from humours in the blood that was thought to fill the arteries and the nerves. ${ }^{15}$

Pietro Pomponazzi (1462-1525), influenced by Alexander of Aphrodisias, argued in his scandalous Tractatus de immortalitate animae (published 1516) that Aristotle's analysis of the soul in De anima is inconsistent with the soul's immortality; since Pomponazzi is not denying the latter, he infers that we can only know it through faith, not reason. In chapter 8 of this work, he specifically claims that the human soul is always dependent on its organs (a view familiar from Galen's late treatise on the soul's dependence on the body), and is hence material. Discussing Aristotle's doctrine of imagination (phantasia: cf. De anima, 431a16-17), he insists that it entirely the product of material, sensory interactions. ${ }^{16}$

The ease with which Aristotle could be taken up in a naturalistic project malgré lui (like Malebranche could in the late seventeenth and early eighteenth centuries) was noted early on by Pierre Bayle. In the entry "Pereira" of his Dictionnaire, Bayle remarks with many conditionals that "one might believe" that "Aristotle only granted a difference between the animal soul and the human soul in terms of greater or lesser [capacities] of organs (une différence du plus au moins)"; this merely quantitative difference would entail that the human soul could carry out subtle reasoning, while the animal soul could only do so "in a confused manner." And this "confirms the claim of those who say he [Aristotle] did not believe in the immortality of the soul." 17 To be clear, Bayle is not agreeing with the view, but is noting the ease with which it can be proclaimed, and credited to Aristotle.

Thus natural philosophy by the mid-sixteenth century produced a concept sometimes referred to as the 'organic soul', in which the concept of soul - at some distance from Christian eschatology - becomes primarily an explanatory, natural-philosophical construct for our animating life functions, and how these relate to human intellective or rational capacities. As Park defines it, the organic soul is "the principle responsible for those life functions inextricably tied to the bodies of living beings and immediately dependent on their organs." 18 Simpler, baser life functions of nutrition, growth and

\footnotetext{
${ }_{15}$ Park 1988, p. 483; she mentions Melanchton and Telesio, to which we can add Pomponazzi and Cardano.

16 There are multiple strands of these naturalistic reinterpretations of Aristotle; for instance, the anonymous manuscript of 1659 Theophrastus redivivus tries to restate Aristotle's Prime Mover in these terms (Paganini 1985).

17 Bayle, "Pereira," remark E, in Bayle 1740, vol. 3, p. 653; see Paganini 1985.

18 Park 1988, p. 464. See also Sutton forthcoming.
} 
reproduction were observed across different species, but sensitive, even cognitive, life functions were observed and collected into another level of organic soul. While the localisation of vital and cognitive functions was already an ancient research program ("among the ancients, there were many who located the soul in the brain, the heart, the chest, or 'in some hidden place, from which like a spider it runs through the whole body when opportunity bids'"19), as can be seen in the above discussions of De anima, this increasingly becomes a vision of organic unity, with a growing emphasis on physiological explanations of parts of the soul. In some cases, physiology was the deciding factor in an argument, and even forced substantial revisions to common doctrine. ${ }^{20}$

In medicine - and radiating outwards across disciplines, as exemplified with humoralism and the notion of melancholy - this Aristotelian or postAristotelian faculty psychology is combined with the Galenic humoral doctrine, providing a framework for understanding health, disease, and temperament which spanned cognitive, vital, and nutritive activity. A key text here is Galen's late and rather provocative short treatise (sometimes referred to as a pamphlet), That the Faculties of the Soul Follow the Mixtures of the Body, or in shorter form The Soul's Dependence On The Body. ${ }^{21}$ According to Galen, the character or "substance of soul" is determined by, or 'follows upon' the mixture (kraseis: also 'temperaments'22) of elements in the body, which, in its turn, depends on diet and daily activities. The soul has three faculties (dunameis) that have their seats in specific bodily organs: reason is located in the brain, volition and courage in the heart, and desire in the liver; e.g., the reasoning faculty will be a "mixture within the brain" (p. 153). A surplus of yellow bile in the brain, for instance, results in madness, and an accumulation

\footnotetext{
${ }^{19}$ Des Chene 2000, p. 191, citing the Coimbra Jesuit commentaries on De Anima.

${ }^{20}$ Park 1988, p. 483. The soul as life function continues to be invoked at least as late as Descartes's discussion with Plempius on how a heart freshly extracted from a living body continues to beat. As Lucian Petrescu shows (Petrescu, ms. 2012), Descartes uses Plempius' observation as an argument against the motor force of the sensitive soul: the soul is not supposed to remain and act in a dead heart: "how ... can the movement which occurs in the cut-up bits of the heart depend on the human soul, when it is taken as an article of faith that the rational soul is indivisible, and has no sensitive or vegetative soul attached to it?" (AT I, p. 524 / CSMK, pp. 80-81). Thanks to Lucian Petrescu for sharing his work on Plempius and Descartes with us.

${ }^{21}$ Galen 1997, pp. 150-176. The original title is Quod animi mores sequuntur temperamenta

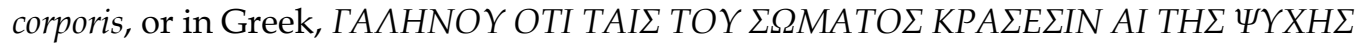
$\triangle Y N A M E I \Sigma$ EПONTA.

${ }^{22}$ Krasis is usually translated as 'blending' or 'mixture'; our temperament is the result of a given humoral mixture (hence 'idiosyncrasy', idiosunkrasia), to which Galen devotes a separate treatise, On Mixtures.
} 
of black bile in melancholy ${ }^{23}$ (thus eukrasia is the healthy balance of the elements while dyskrasia is an imbalance, which is a cause of disease). Health is defined as a proper mixture of the four humours, and a concomitant equilibrium in the balance of the four qualities.

More provocatively, Galen goes so far as to affirm that soul and its parts actually are the temperaments of organs in which they reside: the mortal part of the soul (although he is at best agnostic, and in fact sceptical regarding the immortal part) is just "the mixture of the body"24; even if there were a "separate substance" for the soul, it would still be dependent on ("a slave to") the mixtures of the body (p. 155). That is, given the presence of these various humoral mixtures in any part of our body, the soul "cannot but be a slave to the body"; but Galen then modifies this into an identity statement (rather than one of dependence): "it is preferable to say ... that the mortal part of the soul is the mixture of the body" (p. 157, emphasis ours). We could immediately label this a medical materialism, but Galen goes in a slightly different direction - still reductionist but more practical than ontological. On the basis of his vision of soul as produced by humoral mixture, he derives a further thesis: doctors rather than philosophers should be entrusted with the education or re-education of individuals, to lead them towards virtue. As Lamy and La Mettrie will loudly proclaim (and as we discuss later on), doctors can and should play this role precisely insofar as they are in a position to modify the moral and intellectual qualities of the soul, since it is viewed as dependent or 'following upon' the temperaments of the bodily organs. Hence the soul will be responsive to changes in diet, environment and overall tenor of life which medical science will manage.

Galen's idea that the soul is susceptible to disease, and hence mortal, was also to be a powerful stimulus to heterodox, naturalistic and ultimately materialist arguments concerning the soul. This was seen early on and aroused both Platonic and Aristotelian-inspired responses. ${ }^{25}$ Some defend the view that the soul is the form of the body - indeed the form that gives existence (actuality) to the living body - and thus a special, irreducible substance, rather than an accident of the body as a complete substance. The

\footnotetext{
23 Bos 2009, pp. 35-36.

24 Galen 1997, pp. 153, 157.

${ }^{25}$ For Platonic responses to Galen, see Hirai 2011, ch. 2 (on Jean Fernel's Christianised-

Platonic reaction to the resurgence of Galenism); for Aristotelian responses, Des Chene 2000, ch. 4, and for Renaissance responses (and artful combinations of Aristotle, Hippocrates and Galen) within a medical context, Martin forthcoming.
} 
dependence relation goes the other way round, on this view. ${ }^{26}$ Galen had already reacted to Aristotelian counter-claims by granting that the soul is the form of the body - but in the sense that the parts of the soul are the forms of each corresponding bodily organ.

Interestingly, some Aristotelians could perfectly well accept that the soul is affected when the body's qualities are altered; but they then added a categorical challenge: as Des Chene puts it, the question is not whether some parts of the soul are affected or not, but "what that tells us about the category to which the soul belongs." 27 This will be rearticulated as a transcendental argument against humoral medicine and/or the psychophysiology of animal spirits, by various thinkers including Malebranche, Cudworth and Berkeley. ${ }^{28}$ In the 1640s, Sir Thomas Browne, who was willing to accept the Galenic 'evidence' that the soul, for "the performance of her ordinary actions," requires both a "symmetry and proper disposition of organs" and a "crasis (i.e. krasis, CW) and temper correspondent to its operations," nevertheless considered that all of this "flesh" was the "instrument" of the soul, not the soul itself. 29

This fear of contamination, disguised as a diagnosis of a category mistake, was justified if we consider the legacy of Galenic humoralism as 'humoral materialism', for in addition to the blurring of 'disciplinary' discursive boundaries between medicine and philosophy, it challenges one of the more powerful arguments in favor of substance dualism: the noncommunicability of thinking substance and extended substance, or more aptly put, of soul and body. ${ }^{30}$ Thus Timothie Bright, the chief physician at St Bartholomew's Hospital in London, in his 1586 Treatise of Melancholie (which influenced Shakespeare's usage of the concept in "Hamlet" 31 ), is concerned with how "the body and corporall things, affect the soule," and how the soul affects the body in turn. ${ }^{32}$ Whatever the effects of the body on the soul may be,

\footnotetext{
26 Des Chene speaks of “ontological dependence" (Des Chene 2000, pp. 71-72). Cesare Cremonini makes just this charge: that contemporary Aristotelians are inverting the causal relationship between soul and body (see Martin forthcoming).

27 Des Chene 2000, p. 71.

${ }^{28}$ Berkeley insists that "the soul is indivisible, incorporeal, unextended, and ... consequently incorruptible"; the decay and dissolution which occurs in natural bodies "cannot possibly affect an active, simple, uncompounded substance"; hence "the soul of man is naturally immortal" (Berkeley 1710, I, § 141 in Berkeley 1999, p. 87).

${ }^{29}$ Browne 1892, § XXXVI, p. 78.

30 Galen 1997, pp. 282-283.

${ }^{31}$ Dover Wilson 1935, pp. 227, 309f. Bright was also the inventor of modern shorthand (see his 1588 Characterie: an Arte of Shorte, Swift, and Secret Writing by Character). For more on Bright on humours see Henry 1989 and Wright 2000.
}

32 Bright 1586, Epistle Dedicatory, n.p. = p. iv. 
these cannot bring about, Bright insists, any "alteration of substance, or nature." 33 Namely, the idea of a communicability between body and soul via humours is a kind of category mistake, and a dangerous one. While Galen himself did not make any overt philosophically reductionist claims (as distinct from claiming to provide a medically reductionist account), in an early modern context these ideas, whether directly quoted or modified, sound quite different, e.g. when the Gassendist François Bernier suggests that "it would appear that Galen was persuaded the Soul was a spirit that emerged out of the blood," 34 or when Browne alludes to the 'wrong' sort of influence Galen could have: "I remember a Doctor in Physick, of Italy, who could not perfectly believe the immortality of the soul, because Galen seemed to make a doubt thereof." 35

In positive terms, this type of integrated view meant that "moral physiologists and medical psychologists alike could draw especially on rich traditions of psychological explanation in terms of alterations in the animal spirits." 36 Consider Robert Burton in his sui generis cultural-humoralist treatise The Anatomy of Melancholy, first published in 1621. Burton allows for an interaction between different kinds of "distraction" in body and soul:

For as the distraction of the mind, amongst other outward causes and perturbations, alters the temperature of the body, so the distraction and distemper of the body will cause a distemperature of the soul, and 'tis hard to decide which of these two do more harm to the other. ${ }^{37}$

How can the body, which is material, work on the immaterial soul? By means of humours: "the body, being material, worketh upon the immaterial soul, by mediation of humours and spirits, which participate of both" (ibid.).

In negative terms, consider also that Burton speaks of the rational soul as a "pleasant but doubtful subject." 38 Even when physicians insisted that they were working within a circumscribed profession, and not seeking to be metaphysicians, their success could plead against them: thus Bright saw that precisely the success of physicians in curing diseases which involved 'the

\footnotetext{
33 Bright 1586, ch. X, p. 39. On Bright's warnings about the implications of the humoral concept see Trevor 2004, p. 49.

${ }^{34}$ Bernier 1678, vol. V, p. 452, and generally vol. V, book VI, ch. iii: "What the animal soul is."

35 Browne 1892, § XXI, p. 45.

36 Sutton forthcoming; Sutton 1998, pp. 31-49; Iliffe 1995, pp. 433-434.

37 Burton 1628, I, v, 10, "Continent, inward, antecedent, next causes and how the body works on the mind."

38 Burton 1628, I, ii, 9, “Of the Rational Soul."
} 
soul" implied that virtue and vice would gradually become "nought else but fault[s] of humour." 39 It was thus was a natural reaction to suspect atheism, whether willing or unwilling, in these increasingly imperialistic statements of medical 'pneumatology' - which, as we shall see below, is precisely what Willis's neuro-anatomical and metaphysical reconfiguration of the soul brought about.

From the organic soul to humoral medicine (and its philosophical ramifications or interpenetrations), soul and body are "continuously resubjected to a series of mappings, and experts recognised that this relationship was one of mutual causation." 40 In disciplinary terms, this should modify the presentation found of the 'mind-body problem' in early modern philosophy, since here we have a concept of soul as a product (loosely defined) of medical, anthropological, physiological knowledge, ${ }^{41}$ which is effectively travelling back and forth between natural-philosophical, medical and metaphysical discourses.

\section{The interpenetration of medicine and metaphysics: models for the material soul}

The soul is thus a go-between concept, a "boundary concept" 42 which crosses the borders between life sciences and metaphysics, but also between medicine and theology. For just as there were theologically motivated medical works such as Thomas Browne's 1643 De religio medici (which begins with Browne deploring rumors of doctors being atheists as the "general scandal of my Profession"43), there were also medically motivated works of radical or heretical theology, engaging in polemics such as that concerning the immortal or mortal soul, ${ }^{44}$ which, as the previous section should indicate, were something like low-hanging fruit for naturalistically inclined thinkers. One of these partly polemical works bears the explicit title L'âme matérielle, and we will return to it in the final sections of this essay.

This role of the medical works - and their impact on 'philosophical' works which deliberately locate themselves at the intersection of medicine, natural philosophy and (heterodox) metaphysics, like L'âme matérielle or, to an

\footnotetext{
${ }^{39}$ Bright 1586, Epistle Dedicatory, n.p. (= p. iii).

40 Iliffe 1995, p. 433.

41 Iliffe 1995, p. 434. The tenor of our discussion owes a lot to the stimulating analysis in

Sutton forthcoming.

42 Star and Griesemer 1989.

43 Browne 1892, § I, p. 1.

44 The best study of this is Thomson 2008; see also Vartanian 1982, Thomson 2006.
} 
extent, La Mettrie's writings - is systematically underplayed or unnoticed by commentators.

Historians of philosophy (here, Garber in an impressive survey of the issue) tend to present the situation of the soul in the seventeenth century as "by and large about the ways in which philosophers either make use of or reject incorporeal substance in accounting for life and other features of the physical world." 45 Earlier traditions remain, but the idea of the soul is no longer tied to form and matter. "It is a question of what (if anything) we must add to body, a question of establishing the limits of what can be explained in terms of body alone, and what must be posited over and above body." 46 For natural philosophers, this is a question of body qua matter, but for physicians it is mostly a question of body qua human body (or a comparative approach to human and animal bodies), and this is missing from the above analysis. The soul does not have to be derived from an analysis of substance.

Physicians like Thomas Willis read the existence of the soul from the nature of the human being and others in a more explicit Epicurean context (from Gassendi to Lamy) sought to integrate the "life of the soul" with medicine and thereby modify metaphysics, turning it away from, e.g. substantivalism, while also stressing either the Galenic theme of the soul as "mixture of the body" or the lack of any categorical separation between animal and human souls (Pomponazzi). Garber's characterisation of the use or rejection of incorporeal substance is a useful philosophical reminder, but metaphysicians were not the only students of the soul. What is missing from view here is that, whilst physiological studies are the primary operation of the physician, these are not conducted without reference to the soul. As Katharine Park puts it, referring to the work of Walter Pagel,

Some began to approach the vexed problem of the origin of the soul as a problem in embryology rather than in metaphysics or theology; for many sixteenth-century philosophers, unlike their medieval predecessors, the answer lay in the sequential development of the organs rather than in the successive infusion of different levels of soul. ${ }^{47}$

A different point from Garber's, but which also runs somewhat counter to the narrative of this essay, and the texts discussed here, is John Henry's, stressing the existence of a real divide between medical and philosophical

\footnotetext{
45 Garber 1998, p. 763.

${ }^{46}$ Garber 1998, p. 762.

47 Park 1988, p. 482, citing Pagel 1967, pp. 233-247 (thanks to Benny Goldberg for this reference).
} 
texts in the period, such that that radical and atheistic ideas are more influenced by Hobbes, Epicurus et al. than by the 'medicalisation of the soul' we are interested in. ${ }^{48}$ He grants that Glisson's 1672 treatise On the Energetic Nature of Substance is an exception, but notes that it was difficult and not widely discussed. The type of texts we deal with here, while they indeed did not circulate the way the writings of Hobbes or Spinoza did (and lack their fame over subsequent centuries), are a clear counter-example to this claim of Henry's (repeated uncritically by others).

It is not easy to reduce the history to either a clear conceptual claim or a set of neatly demarcated traditions and contexts, but in contrast to the disciplinary boundaries which both Garber and Wright seem to explicitly rely on, we would point to (i) the naturalistic appropriation of Aristotle's De anima, itself part of a trend we might call (ii) the medicalisation of natural philosophy, (iii) the Galenic challenge to traditional philosophical concepts of soul in medical terms, and (iv) the emergence of a 'humoral materialism' to which physicians such as Timothie Bright could react, as we saw above, with concern about what would befall the concept of an immortal, immaterial and causally 'out of reach' soul, if temperament could be explained in terms of humours. In this sense, Rob Iliffe is closer to our view when he writes that "In an important sense, the soul - its location and its function as the active and moral essence of the individual - should be seen as the product of this forensic and physiological knowledge." 49

Similar to the analysis of the 'organic soul' in previous centuries, the idea is that theorists of the soul gradually moved away from traditional 'parts of the soul' representations, and "drew more and more from contemporary work in medicine, though this was of course still limited by theological doctrine" (ibid.). And contrary not just to mainstream history of philosophy but also history of medicine, this productivity of the concept of soul (naturalistically reconfigured) extends beyond Cardano, Willis and Lamy, for some observation reveals that up to the beginning of the nineteenth century, medical thinkers staked out their own scientific views in physiology, pathology but also emerging neuroscience through discussions of the role of the soul in the body. ${ }^{50}$ It should be clear how much this contrasts with the oldfashioned view - here, in the words of Roger French - that "the advance of physiology after Whytt [thus in the last third of the eighteenth century, CW] was an erosion of the concept of soul." 51 The latter view relies on a separation

\footnotetext{
48 Henry 1989, pp. 92-93; repeated as such by Garber 1998, p. 764.

49 Iliffe 1995, p. 434.

50 Wright 1991b, p. 22; Hagner 1992.

${ }^{51}$ French 1969, p. 161.
} 
between an increasingly scientific medicine and a more archaic, metaphysically influenced natural philosophy, which our work (in addition to that of Park, Wright and Thomson) should indicate is in serious need of revision. But elsewhere, in what is in many respects a landmark paper, Wright reintroduces a traditional distinction between what happens in metaphysics, and what happens in medicine, suggesting that substance dualism belongs to metaphysics, whereas function dualism belongs to medicine. 52

In contrast, the present analysis tends to show that they are always combined: physicians claim special authority when making pronouncements on the nature of the soul, and in doing so revise, eliminate and generally appropriate a tradition in which Aristotle, Galen, Pomponazzi or Descartes are as present as 'strictly' medical figures. Conversely, philosophers, particularly those of an Epicurean and/or materialist bent, will invoke medical 'evidence' (from mental trauma and the action of poisons to the behavior of decollated lizards) to support their critiques of the notion of an immortal soul. And at least as far back as Avicenna's reception of Aristotle's De anima and, closer to our period here, Girolamo Cardano's naturalisation of the problem of the soul's immortality, the question of the soul has produced mobile differentiations (partly as a 'go-between', as mentioned above) between a metaphysical approach and a natural-philosophical approach. Cardano even entitled a section at the end of his 1545 treatise De immortalitate animorum, "A digression on the immortality of the soul in a naturalphilosophical fashion" (naturaliter loquens). ${ }^{53}$ Cardano went so far as to claim that medical knowledge was more certain than natural philosophy, which he claimed derives causes from effects, while medicine infers effects from causes. ${ }^{54} \mathrm{He}$ also argued that it was possible to use medical principles to investigate issues of natural philosophy that were not directed toward medical purposes, and cited the third book of Aristotle's Problemata that concerns drunkenness as an example of such an investigation. ${ }^{55}$

We find these episodes to be rather more conceptually significant than appears from the diagnosis given by John Henry, according to which "The eclectic neo-Platonism of the Renaissance gave rise to a number of confusions

\footnotetext{
52 Wright 2000, p. 238.

53 "Digressio de animi immortalite secundum naturaliter loquentes." Thanks to Hiro Hirai for this point.

54 "Et ob hoc intelligimus, Medicinam esse certiorem naturali philosophia, cum naturalis philosophia semper procedat ab effectibus ad causas, Medicina vero persaepe a causis supra effectus" (Cardano 1663/1966, vol. 8, p. 585, cit. in Martin forthcoming).

55 Siraisi 1997, pp. 52-57; Martin forthcoming.
} 
or contaminations between notions of spiritus, pneuma, and anima."56 That various texts sought to bridge the gap between medicine and metaphysics (or pointed to the non-existence of such a gap in both the Galenic tradition and a certain reading of Aristotle on the soul via Alexander of Aphrodisias, the earliest commentator on Aristotle, and Pietro Pomponazzi), or blurred boundaries with their humoral materialism (as seen by Timothie Bright) is rather different from mere "confusion or contamination." Similarly for the later two centuries, when early modern Epicureans discuss the claim found in Lucretius that the words 'mind', 'soul' and 'intelligence' really all mean the same thing, ${ }^{57}$ and do so in texts spanning medicine, natural philosophy and philosophy tout court, it may be "contamination," but not just "confusion," and if it is the former, it deserves to be understood.

Of course, 'soul' is not an unchanging object with fixed contents and boundaries, which itself is trans-disciplinary and can be taken up, here by an English physician, there by a Coimbran Jesuit. Rather, our point, modifying the more traditional distinctions in play in the above analyses, is twofold. First, we note historically that, with figures including Boerhaave, Gaub, Cullen and Le Camus, there was a body-soul problem in and for medicine, growing out of some of the medicalisation of 'pneumatology' in natural philosophy as discussed above (hence, the claim that early modern debates on the soul did not significantly involve medicine would be historically false, or at least in need of significant revision). Second, we note that physicians, natural philosophers, and medically 'influenced' philosophers - both physicians writing 'philosophy', like Lamy; physicians who become philosophers, like La Mettrie; and philosophers whose career reflects a continuous engagement with developments in medicine and physiology, like Diderot - engage with this medical version of the body-soul problem and thereby bring about a naturalisation ${ }^{58}$ of the soul, and more generally are the first to defend naturalistic arguments in philosophy (understood as arguments which seek to show that a scientific concept or discovery can have direct bearing on philosophical claims; and here the Epicurean tradition is very present).

Why was there a 'body-soul' problem in medicine, and what was it? The first context that comes to mind is Cartesian; entire books have been

\footnotetext{
${ }_{56}$ Henry 1987, p. 23 (reprising a point made in Walker 1984).

57 Yvon 1765 , p. 570.

58 On the idea of a 'naturalisation of the mind' in the early radical Enlightenment which is not quite an elimination of mental or animate properties in favor of the properties of basic matter, see Wolfe 2010; Hatfield comments that "Ontological questions were bracketed in order to concentrate on the study of mental faculties through their empirical manifestations in mental phenomena and external behavior" (Hatfield 1995, p.188).
} 
written just on the specifically medical context of Cartesianism. ${ }^{59}$ Both during Descartes' own lifetime and in the following decades, numerous physicians claimed to be carrying out a legitimate Cartesian project, e.g., eliminating final causes and explaining all of nature mechanically, including the human body, while in fact moving ever closer to Spinozism and/or materialism. Thus Henricus Regius (Hendrik le Roy), a physician and Professor of Theoretical Medicine at the University of Utrecht, often called the 'first apostle of Cartesianism' (e.g. in a review in the Nouvelles de la république des lettres in October 1686), asserted that the soul could be a mode of the body, with the body being understood as a machine, and that the human mind, inasmuch as it exists in a body, is organic. ${ }^{60}$ Even Marx (stealing from Renouvier's history of philosophy) mentions Regius as a precursor of La Mettrie: “Descartes was still alive when Le Roy applied to the human soul the Cartesian idea of animal structure, and declared that the soul was but a mode of the body, and ideas were but mechanical motions." 61 Others asserted that Descartes was too timid, and one should be a Cartesian in physiology while eliminating substance dualism, in favour of a parallelism of physical events and mental events (Louis de La Forge ${ }^{62}$ ), or, rather tortuously, tried to argue 'from' Descartes towards a materialist account of mind-body interaction (Antoine Louis, J.-B. Du Hamel, Pierre Dionis - influenced by Lamy - and others). Such thinkers tried to collapse their ideas into Descartes' own, but others - perhaps tellingly, outside of France - were quicker to dispense with any monopoly Descartes might have had over the prestige of mechanism in medicine, like Herman Boerhaave (1668-1738) or Hieronymus Gaub (1705-1780).

Boerhaave's 1690 doctoral thesis in philosophy at Leiden, where he was later Professor of Medicine, Botany, and Chemistry (he was widely viewed as the most influential lecturer in medicine in Europe, and taught figures including La Mettrie, Gaub and Haller) was entitled De distinctione mentis a corpora, and there he argued for a distinction between mind and body. But in his later Praelectiones academicae (Boerhaave 1739), he denied any medical or physiological pertinence to the substantival distinction between body and soul or mind ( $\$ 27)$. Body and mind are united, communicated, mutually affect one another, and a change occurring in the one produces a change in the other (a view which may explain the unfair accusations of Spinozism that were laid against him). Boerhaave admits that he has no way of explaining this interaction experimentally (something La Mettrie is quick to

\footnotetext{
59 Most recently, Bitbol 1990, Aucante 2006, and Manning 2007 (a useful review essay).

${ }^{60}$ Regius 1646, pp. 248, 246.

${ }^{61}$ Marx, The Holy Family, VI, 3, d, discussed in Bloch 1977.

62 de La Forge 1666, ch. XV.
} 
fill in, both in his edition and translation of Boerhaave's lectures, La Mettrie 1747 and in his own writings); he considers three hypotheses, "physical influx," occasional causes and divine harmony, and opts for the last (§ 27.7). He adds a remark that was repeated, with or without attribution, many times during this period (similar comments can be found in Galen): physicians should only concern themselves with the body, even when dealing with mental illness (or 'diseases of the soul'), for once the body is working correctly, the mind will return to its proper "officium" (§ 27.8) - the ancient Stoic term for the role we are destined to play, which in this context can be rendered as "function." 63

Boerhaave's student Gaub, who took over his Chair in Leiden, gave a lecture there in 1747 which La Mettrie claimed to have attended (some months prior to finishing L'Homme-Machine), entitled De regimine mentis (translated in Rather 1965). This text is important for us because there Gaub articulates - or at least suggests - a clinical perspective on the problem of mind-body interaction (for he is speaking of mens rather than anima). ${ }^{64} \mathrm{La}$ Mettrie spoke favourably about the ideas he heard, and his enthusiasm (more on which in our penultimate section) makes sense, for Gaub had defended the view that for the physician, the metaphysical distinction between mind and body is irrelevant. "Although the healing aspect of medicine properly looks toward the human body only, rather than the whole man, it does refer to a body closely united to a mind and, by virtue of their union, almost continually acting on its companion as well as being itself affected in turn." 65 Gaub refers to the authority of Descartes, "the most ingenious philosopher of his age," who "yielded to physicians" regarding the priority of medicine in these matters (p. 74)66, and states that due to the variability of temperaments, itself explainable in humoral (and hence medical) terms, the philosopher "cannot dispense with the aid of the physician" where the mind is concerned (p. 86).

So whereas some of the Cartesians, Boerhaave and Gaub thought that the body-soul union (or relation, depending on their convictions) fell under

\footnotetext{
${ }^{63} \mathrm{On}$ 'officium' or 'office' as a functional, teleological or 'teleomechanical' concept in early modern medicine, see Wolfe forthcoming 2012.

${ }^{64}$ Wright 2000, p. 249. Gaub, like Haller, did not appreciate La Mettrie's materialist appropriation of his ideas, and in 1763 included a short essay against La Mettrie in his new edition of De regimine mentis (Rather 1965, pp. 115-117), calling him "a little Frenchman" who produced a "repulsive offspring ... his mechanical man" (Gaub 1763, in Rather 1965, p. 115).

${ }^{65}$ Gaub 1747, in Rather 1965, p. 70, emphasis ours.

${ }^{66}$ Gaub has in mind the passage from Part VI of Descartes' Discours de la méthode where Descartes notes the interpenetration of mind and the organs of the body, so that medicine is the best way to render people wiser than they have hithertoo been (AT VI, p. 62). Lalande observed in 1911 that similar remarks on the philosophical value and primacy of medicine can be found in Bacon's De dignitate et augmentis scientiarum, IV, 1-2 (Lalande 1911, p. 305).
} 
the medical purview, but that it was perhaps best to focus on the body, others were more aggressively materialist in asserting the autonomy of medicine with respect to theology or other disciplines. Thus Boerhaave's advice to physicians (only concern yourself with the body) becomes, in the Montpellier physician Ménuret de Chambaud's entry "Mort" in the Encyclopédié, free of earlier niceties:

The separation of the soul from the body, a mystery which may be even more incomprehensible than its union, is a theological dogma certified by religion, and consequently is uncontestable. But it is in no way in agreement with the lights of reason, nor is it based on any medical observation; hence we will not mention it in this purely medical article, in which we will restrict ourselves to describing the changes of the body, which, as they alone fall under the senses, can be grasped by the physicians, those sensual artists, sensuales artifices. ${ }^{67}$

Here the medicalisation is administered in such strong doses that the concept of soul falls out altogether (and it is noticeable that the physician who wrote this article is 'trespassing' into theology or its opposite, with the term "mystery").

But these attempts to articulate and justify a specifically medical approach to body-soul relations (which, by the later eighteenth century, are gradually being termed 'body-mind' relations, although this is not at all absolute) can also accept substance dualism, albeit idiosyncratically. William Cullen, in physiological lectures given at the Royal College of Physicians of Edinburgh in the mid-1760s, reflects on substance dualism, not in order to reject it, but to give it a peculiarly medical cast. For Cullen, we can know the mechanism(s) governing our bodies, not that which governs our minds. Yet, like Boerhaave, he also thinks that our mental states are inseparable from "some conditions in the body." 68 Perhaps on ideological grounds, Cullen immediately appeals to the good reputation of Boerhaave and Haller, who were never "suspected of Irreligion" (ibid.). However, he also recognises that the mind-body problem remains problematic, including for physicians; and yet, the specifically medical version of the problem as he states it sounds much like a materialist statement (granted, an embodied materialist statement) from Diderot or La Mettrie. For Cullen reduces "the problem of the action of the mind upon the body" to the problem: "how one State of the body or of one part can affect another part of it" (ibid.). Of course, when Diderot says

\footnotetext{
${ }^{67}$ Ménuret de Chambaud 1765/1966, p. 718b.

${ }^{68}$ Cullen, notes added to “Lectures on the Institutes of Medicine," cit. in Wright 2000, p. 244.
} 
such things (discussed below) he does not intend them to be circumscribed to medicine; rather, he (and La Mettrie) introduce into philosophy a naturalistic type of argument derived from the medical evidence (or theorizing).

Similar (although not in medical-historical terms) to Cullen's way of defending substance dualism while insisting on a specifically medical variant, the Paris physician Antoine Le Camus, in his Médecine de l'esprit (1753), put forth the program that medicine should know both minds and bodies, so that it can perfect the mind by acting on the body. Le Camus notes that most people would not deny medicine's expertise when it comes to the body, but they would be reluctant to grant it authority over the mind, and he wants to remedy this situation: "to remedy to the vices of the mind is nothing other than to remedy the vices of the body." 69 Although phrased in terms of Cartesian dualism, Le Camus' conception of medicine and of therapeutics is a different creature, for it belongs to the conceptual scheme of the "animal economy" - a more integrated, organisational approach. ${ }^{70}$ Though his title suggests that Le Camus is a sort of Cartesian (since the Cartesian thesis is that passions are effects of the mind-body union on the mind), he has more of an expansive conception of medicine, which we can consider as an outgrowth of the material soul concept. Similarly, Le Camus gestures initially in a Cartesian direction, saying he knows the soul is rational and immortal, but he immediately adds that it is also true that the soul is "aided in its operations" by "genuinely mechanical causes." 71 Whereas in some cases it was important to show that the medical dimension was an embodied dimension, Epicurean, and in other cases the medical argument is a strictly reductive argument (as in Ménuret), Le Camus's program for medicine holds that it is the science which has equal knowledge of mind and body, and hence can treat their "abstract combinations," and their "relations" (commerce). While terminologically he still refers to these as two substances, in practice he gives an integrated account of "virtues" and "passions" as being as much part of the body as of the soul. 72

From the medicalisation of natural philosophy in Cardano to the emergence of a specifically medical form of the body-soul problem in Boerhaave, then Le Camus, we hope that several points emerge clearly: (a) that it is a mistake to rule out medicine from an understanding of debates on the soul, particularly heterodox approaches to conceptualising the corporeal

\footnotetext{
${ }^{69}$ Le Camus 1753, I, p. 7; "God only excites ideas in our souls relative to the dispositions in our bodies" (ibid., ch. III, section 2, p. 49).

${ }^{70}$ Huneman 2007, p. 266; see also Rey 2000.

${ }^{71}$ Le Camus 1753, I, p. xviii.

72 Le Camus 1753, I, p. 111f .; II, p. 239.
} 
soul (and ultimately the material soul), and restrict that understanding to metaphysics (Garber 1998), or (b) to judge the overlap between these disciplines as merely "confusing" (Henry 1989). Rather, (c) some began to approach the question of the soul - its nature, its origin, and relation to the body - as a problem in embryology (Park 1988), medicine and natural philosophy overall, rather than in metaphysics or theology (Iliffe 1995, Sutton forthcoming). And this new approach is a major step towards the concept of a material soul, e.g. the materialisation of the soul "understood as the function of a particular organised structure."73 It was once debated whether these heterodox approaches to the soul were more Epicurean or more Cartesian (in the sense of a late, medically focused and/or radicalised Cartesianism). But as concerns the present paper, most of the significant and original texts we deal with - obviously Lamy, L'âme matérielle and La Mettrie - are more or less deliberate fusions (or at least blends) of the two, so this question recedes in the distance. ${ }^{74}$

One can thus speak, not just of overlap but of a rich and complex interrelation of medicine and metaphysics on the question of the soul. But we have not yet reached an understanding of the specific notion of the material soul. For that we need to turn back to the late seventeenth century, in the next three sections: the place of the soul in the emerging neuroscience of the period, with Willis (section 4); the resources for a psychophysiology of animal spirits contributed by Malebranche (section 5), and the Epicurean concept of material soul put forth by Guillaume Lamy (section 6). Then we turn to the early eighteenth-century manuscript entitled L'Âme Matérielle (The Material Soul), in section 7; the reception and transformation of these ideas in materialist thought of the next generation (section 8), and conclude (section 9).

At the risk of oversimplifying, we suggest that what was meant to be merely a part of the soul we have in common with animals - and a subaltern

\footnotetext{
73 Vartanian 1982, p. 152.

${ }^{74}$ The older view was Vartanian's (who pointed to a hybrid of Malebranchian and Lucretian 'pneumatologies' in Meslier's Testament, Vartanian 1982, p. 154), much criticised by Thomson, who however did not replace it with another, clearly stated thesis but instead showed that particular textual passages contradict Vartanian's model. Paganini has argued for a third model of material soul, neither Epicurean (Gassendi, Lamy) nor post-CartesianMalebranchian (L'âme matérielle, La Mettrie, obviously combined with the former model). He suggests that the other major clandestine work of the period, the 1659 Theophrastus redivivus, shows the presence of a specifically Averroist-Paduan model of the soul as "actus corporis organici," as elaborated e.g. in Pomponazzi's 1516 Tractatus de immortalitate animae, ch. IX (Paganini 1985, p. 349f.). But it is not clear what impact this model had as such, since when it is discussed (typically in order to combat its 'mortalism'), it is usually fused with variants of the other two models (Mothu 1990-1991, p. 391, n. 273) - and after all, the soul as material in an atomistic sense, as subtle fire or wind in a later Epicurean sense, and as the functional 'act' of an organic body, are all material soul concepts!
} 
part at that - is gradually expanded in explanatory scope (notably through Willis' work on Anima brutorum) until it comes to be a full-blown monistic concept: the material soul (from Lamy to La Mettrie).

\section{The anatomy of brutes and the corporeal soul: Willis}

Thomas Willis (1621-1675) was Sedleian Professor of Natural Philosophy at Oxford (where Locke was one of his students, attending lectures in the 1660s which included material later published in De anima brutorum) and also taught medicine in London, where he was an eminent physician; he was a founding member of the Royal Society. He is best known for his discovery of the 'circle of Willis' and his great work on the anatomy of the brain, the 1664 De cerebri anatome. Willis interlinks anatomy, the brain and the soul in a variety of works, but the one which primarily concerns us here is his later De anima brutorum (1672; English translation 1683), for it is there that he puts forth an extensive concept of "corporeal soul," and somewhat unwittingly provides resources for further materialisation of the soul in toto.

Willis' account of the soul breaks down into three parts: a chimiatric theory (a chemical matter theory with particular focus on life functions), localised physiological explanations of cognitive processes, and the derivation of an incorporeal human soul on the basis of comparative anatomical studies - which is at the same time a blurring of the divide between the corporeal soul and the incorporeal soul. If one compares Willis to Descartes, the difference in their approach to matter is striking: whereas Descartes conceives of it mathematically, Willis is interested in its behaviour. When examining, e.g., the brain, he wants to know how it functions, where all the impressions from the nerves collect and are processed. Because it is not easy to immediately 'read' functions from anatomy, Willis uses comparative studies to eliminate certain structures or functions of the brain, in order to both localise certain functions, and also generalise functions across species if the same basic structures are present - for instance, by classifying different types of animals in terms of respiration, humours and blood, ${ }^{75}$ he can then go on to provide functional descriptions of different classes of animals. The same structures are seen by Willis to be replicated across species to varying degrees of complexity. Differences across species, such as the size and structure of the cerebral cortex, suggest the location of higher order functions such as

75 Willis 1683, ch. III, p. 7. 
memory; whereas similarities, such as the near identical nature of the cerebellum across species, suggest baser, automatic functions. ${ }^{76}$

Comparative anatomy both produces and complicates Willis' account of the soul, but it is a method and a theory which is inherently organic. The human being is the origin and focus of his study, and is compared, not to the workings of nature, but to other living beings. One can see the organic soul taking shape in the emerging neuroscience of the seventeenth century. Willis describes complex cognitive processes in terms of the operation of animal spirits localised to different parts of the nervous system, largely based on comparative anatomy. He locates the imagination or "phantasies" in the middle or medullary part of the brain. ${ }^{77}$

The nervous system of man is at once more refined and complex than any other animal, but so analogously constructed as to be indistinguishable in terms of cognitive function by any physiological principle. For Willis, structure and function are intimately linked. He can find no sufficient physiological difference between human beings and animals to account for their differences in cognitive capacity. ${ }^{78}$ His conception of an organic soul is so strong as to only infer an immaterial soul from the limits of the human body. Another functional claim deriving from Willis's anatomical inquiries was that in the cerebrum, spirits flowing up through the spinal column form imaginations, sensations and memories by virtue of their motions, and then flow back out of the cerebrum to produce wilful, or seemingly rational actions - and this was why he granted animals not only the powers of sensation, but those of memory and even a lower 'brutish' rationality. In contrast, the cerebellum regulates the involuntary motions - from the cardiovascular system to digestion and even sexual arousal. Part of Willis's justification for this division between cerebellum and cerebrum, which he maintained in both Cerebri Anatome and De Anima Brutorum, was the fact that animals seemed to have smaller cerebrums and larger cerebellums. But because humans are also animals, we also have a cerebellum. And motions in the cerebrum can disturb our otherwise involuntary functions. ${ }^{79}$

Willis connects the different areas of comparative anatomy, the neurophysiology of animal spirits, a chimiatric conception of matter (explaining life through fermentation), and a complex differentiated theory of types of souls, with a strong influence, often acknowledged, of "the famous

\footnotetext{
76 Bynum 1973, p. 451.

77 Willis 1683, ch. VII, pp. 41, 43.

78 Bynum 1973, p. 453.

79 This is the basis for the passions, according to Willis, although he offers no systematic explanatory model (or at least nothing close to that of Descartes).
} 
Gassendus." 80 He endorsed a modified version of what he had read in both Gassendi and in the theologian Henry Hammond: humans all possess a tripartite nature. ${ }^{81}$ Like all animals they possess bodies and sensitive souls, but they also possess a rational soul, and the interrelation between these is the topic of De anima brutorum. Gassendi and the more general streams of Epicureanism associated with him influence Willis, both in the way he grants animals (contra Descartes) not just a sensitive capacity, but a rational one, 82 although he wavers on exactly how much, and in his chimiatric conception of matter - what we might call his pyrotechnic theory of internal chemical explosions in the body, for which he credits Gassendi: "But indeed, the same fiery nature of the soul, serves within the body by its own mobility, what a little flame of gunpowder does in a Cannon." 83

The soul that interests Willis the 'father of neuroscience' and natural philosopher is the corporeal or sensitive soul, responsible for life functions (Willis 1683, p. 2). He divides the corporeal soul into two parts, the vital and the animal. The vital soul is the one he specifies in chemical and 'pyrotechnic' terms. The sensitive part of the soul is the animal spirits:

There are therefore Corporeal Souls, according to its two chief functions in the Organical Body, viz., the Vital and Animal; two distinct parts, to wit, flamie and lucid, for what belongs to the said natural function, that indeed is involuntary of the Animal, and is performed by the help of the Animal Spirits. ${ }^{84}$

The chemical properties of matter provide a basis for the organic soul, but it is in the operation of the body that this soul reveals itself. Animal spirits, considered as inherently volatile and active, play an important role in this conception of matter, which is chemically specified. The animal soul is "of a certain fiery nature, and its act or substance is either a Flame or a Breath, neer to, or a-Kin to Flame" (p. 5), its life is an "Inkindling of the Vital matter" (p. 7), and "the Part of the Corporeal Soul rooted in the Blood, is truly flamy" (p. 22). In rather lyrical terms, Willis also approving quotes Hippocrates to the effect that, so long as the soul survives in the body,

\footnotetext{
${ }^{80}$ Willis 1684, p. 2; Willis 1683 opens with an admiring summary of Gassendi.

${ }^{81}$ Willis 1683 , ch. VIII, p. 40.

${ }^{82}$ See his chapter entitled "Of the Science or Knowledge of Brutes," Willis 1683, p. 32; Wright 1991a, p. 249. The opening pages of Willis 1683 are in part a critique of the animal-machine concept (targeting Descartes and Digby).

${ }^{83}$ Willis 1684, p. 3 (pagination is specific to each text in this collection). Willis also says, however, that Gassendi does not provide the empirical details of how this vital chemistry of flame works (a gap he will presumably try and fill).

${ }^{84}$ Willis 1683, ch. IV, p. 22; see also p. 41.
} 
It is always Born, even till Death, In which respect also, it seems to be most like flame, or rather the same thing, which is continually renewed almost every moment: Some parts of eithers subsistence, in like manner are consumed by burning, and fly away, and others in the meantime are laid up anew from the Food continually laid in. ${ }^{85}$

This quasi-metabolic idea of a perpetual renewal is indeed a chimiatric concept of living matter, and Willis 'cashes it out' through the concept of fermentation. His work on the topic, De fermentatione (1659), was meant to be the introduction to his theory of fevers, which in fact he explained as the outcome of a vitiated fermentation of blood. Is fermentation chemical or mechanical? The chemiatric answer should be straightforwardly the former, since it describes all bodies as being composed of the principles of Spirit, Sulphur, Salt, Water and Earth and the mixture and proportion of these. ${ }^{86}$

But Willis complicates matters by sometimes speaking of fermentation in more purely chemiatric terms, sometimes in more mechanical terms, as a motion of the parts. Ferments helped kindle the particles of spirit and sulphur in the blood into a flame, a combustion that was also called effervescence of the blood, which is how Willis explains body heat and fever. The fermentation in the heart heats the blood like "Water Boyling over a Fire," 87 and this heat is distributed to the whole body through blood circulation, constituting the common cause of ordinary body warmth as well as febrile heat. Our body heat is the effect of a chemical cause - fermentation. And, most relevantly for us, "The first beginnings of life proceed from the spirit fermenting in the heart." 88 Willis also uses the language of life as being like a flame, which as we shall see below, influences Lamy and through him the clandestine materialist tradition that is central to our narrative: "The Life and Flame of the Blood ... are the same (p. 22). And further, "Life is not so like to flame, but even a flame it self" (p. 7). Willis did not limit the interaction between particles to mechanical manipulations, and his understanding of chemical properties and observations of the body led him to conceive of matter as chemical and active,

\footnotetext{
85 Willis 1683, ch. V, p. 29. Interestingly, Harvey also, when reflecting in De Generatione Animalium on the 'epigenesis' of the chicken embryo out of the blood, has the soul "reside" in the blood: "The blood is ... the author and preserver of the body and the principal part in which the soul resides" (Harvey 1651/1981, p. 247f.).

86 Willis, Of Fermentation, chs. I-II in Willis 1659/1681.

87 Willis, Of Feavers, ch. I, $§ 1$, in Willis 1659/1681, p. 59 (pagination continous with Of Fermentation).

88 Willis 1659/1681, ch. V, p. 13.
} 
not inert. ${ }^{89}$ To conceive of matter as "meerly passive" is for him "vulgarly delivered"; rather, and sounding just like Gassendi:

\begin{abstract}
Atoms, which are the matter of sublunary things are so very active and self-moving, that they never stay long, but ordinarily stray out of one subject into another; or being shut up in the same, they cut forth for themselves Pores and Passages, into which they are Expatiated. ${ }^{90}$
\end{abstract}

In sum, Willis has a comparative anatomy project from which he also derives an account of cognitive function, and he has a chimiatric conception of life and disease which occasionally reverberates with Epicurean motifs. But what does he contribute to thinking on the nature, status and types of soul? In his overall scheme, the sensitive soul supplies impressions and ideas to the rational soul by means of the animal spirits, and those ideas are in turn ordered and utilised by the rational soul. The sensitive soul, which governs both life and sensorimotor functions, is in fact corporeal, while the rational soul is not. It is the immaterial, immortal human intellect. The former is sometimes governed by the latter, sometimes dependent on it, sometimes in conflict with it:

The Corporeal Soul does not so easily obey the Rational in all things, not so in things to be desired, as in things to be known: for indeed, she being nearer to the Body, and so bearing a more intimate Kindness or Affinity towards the Flesh, is tied wholly to look to its Profit and Conservation: to the Sedulous Care of which Office, it is very much allured .. . ${ }^{91}$

Thus Willis finds himself dealing with perennial problems of 'communication' between levels of soul: "And so as our Intellect, in these kinds of Metaphysical Conceptions, makes things almost wholly naked of matter, or carrying it self beyond every sensible Species, consider or beholds them wholly immaterial." 92 Indeed, when trying to shed light on the relation between the two souls, Willis can get quite ... metaphysical and opaque, here again building on "the most learned Gassendus": "The Corporeal Soul is the immediate Subject of the Rational Soul, of which, as She is the Act, Perfection,

\footnotetext{
${ }^{89}$ Bos 2009, p. 43.

90 Willis 1683, ch. VI, p. 33. Gassendi in Bernier 1678, vol. V, book VI, ch. iii, e.g. pp. 407-408.

91 Willis 1683 , ch. VII, p. 43.

92 Willis 1683 , ch. VII, p. 39.
} 
Complement, and Form by her self, the Rational Soul also effects the Form, and Acts of the humane Body."93

More concretely (although some historians of science do not find animal spirits a particularly proud moment), Willis's theory of soul is deeply interlinked with his account of how the animal spirits produce sensations and motions, an account which depended almost entirely on his anatomical claims about the brain and nerves. The spirits move through the nervous system in a tonic motion, flowing outward from the brain and returning to it. They "reside in the Organs of the Senses, and are like Watchmen." 94 The motions of the spirits occasion sensations or natural instincts in animals, but they are also the corporeal basis for all human perception. The brain itself is the instrument that facilitated this pneumatic process. Willis's theory of the soul thus emphasises the physicality of the sensitive soul in humans and animals, and the physical motions of these animal spirits through the nerves and brain. He held that the human soul was thus severely limited in its powers by the instruments of the brain, nerves, and animal spirits.

The sensitive soul is produced by the normal motions of the body. As noted above, for Willis there are five major elements: earth, water, salt, sulfur and spirits. Every physical thing incorporates these elements in some form, with the exception of spirits - this is especially true for spirits in the body itself. Willis adheres to a broadly Galenic model of how spirits are distributed in the body, but adds his own theories reflecting contemporary anatomical theories of the time (including those of Harvey). Blood flows to the brain, where the most subtle spirits in the blood are separated from its grosser parts by virtue of the nerves. Willis assumes like many of his contemporaries that nerves are hollow, pneumatic vessels constantly filled with animal spirits, which he defines as the most refined variety of spirit - so refined and so subtle that they were the only physical thing that might possibly be moved by any incorporeal agent. The soul resides at the very center of the brain, specifically between the corpus callosum and the corpora striata, where it receives impressions from the flux of spirits into the brain from the external nerves, and can then return those spirits to the extremities to move the body in various ways. ${ }^{95}$

An important aspect of Willis's corporeal soul that falls outside the province of this paper is the new way in which he rendered the soul

\footnotetext{
93 Willis 1683, ch. VII, p. 41.

94 Willis 1683, ch. X, p. 57.

95 Thanks to Louis Caron for his help with Willis. The literature on Willis has by now reached respectable proportions; we have found Bos 2009, Bynum 1973 and Caron 2011 (chs. 1-3) particularly helpful.
} 
accessible to psychopathology, or conversely, made mental illness an object that could be studied within the naturalistic framework of the new sciences (Conry 1978, Tabb forthcoming). This is because he produces an account of an immaterial soul that is "dependent on the sensitive soul for its proper operation, subject through this dependence to diseases which are potentially curable by physical methods, localised in its seat to a particular portion of the human brain." 96

Our concern here is not Willis's overall impact on thinkers of his time such as Locke, as one of the 'Oxford Physiologists', or on the later history of medicine and neuroscience. Instead, our primary focus is on Willis's contribution to the articulation of the concept of material soul. This includes a willingness to look for types of soul in the context of functional anatomy (in contrast, say, to Descartes, for whom the pineal gland is very much a topdown, a prioristic decision for where to locate these parts of our cognitive faculties), and a complex discussion of how the soul, in its corporeal part but not only, interacts with body, brain, and animal spirits. This is both a major step beyond the gradual privileging of physiology and medicine in metaphysical discussion over the previous centuries (discussed in Park 1988), and a move towards naturalisation, in the sense of a gradual blurring of the divide between human and animal souls. To be sure, Willis's bracketing off of an immaterial, immortal soul in no way reveals a covert atheist or heterodox attitude on his part. ${ }^{97}$ Yet he provides, quite deliberately, a set of major resources for the naturalisation of the soul. We now turn to the other major 'set of resources' for this project, the psychophysiology of Malebranche (which certainly was not a planned legacy on his part).

\section{Resources for a psychophysiology: Malebranche}

Nicolas de Malebranche (1638-1715) certainly considers himself in agreement with Descartes in terms of physiology, with the exception of the pineal gland. "For it must be noted that even when he [Descartes] is mistaken, as seems probable when he assures us that it is to the pineal gland that the soul is immediately united, this nevertheless could not basically invalidate his system, from which we shall always draw all the utility that can be expected from the truth." 98 Malebranche agrees with Descartes that the soul receives

\footnotetext{
96 Bynum 1973, p. 457.

97 See the clear corrective remarks in Henry 1989, p. 98.

98 Malebranche 1674, II.i.1.ii, in Malebranche 1997, p. 89.
} 
new ideas when new traces are imprinted on the brain and vice versa, but he denies that the soul considers these traces in order to sense, imagine or conceive of new ideas:

It is not that it [the soul] considers these traces, since it has no knowledge of them; nor that these traces include these ideas, for they have no relation to them; nor, finally that the soul receives its ideas from these traces; for . . . it is inconceivable that the mind receive anything from the body and become more enlightened by turning toward it. ${ }^{99}$

Descartes' separation of the soul as thinking substance may have brought about a closer study of, and a more intimate relation with, the human body (discussed in the previous section), but it is Malebranche's articulation of this Cartesian science of mind and animal spirits that had the most impact. John Yolton notes that both La Mettrie and Joseph Priestley saw Malebranche as apparently "the first who brought into vogue the doctrine of animal spirits." 100 Further, John Sutton emphasises that "reactions to "the Cartesian philosophy of the brain' owed as much to Malebranche's as to Descartes' version." 101 Indeed, it is clear that Malebranche's impact extended well beyond any mere popularisation of Descartes' ideas, to the development of his own coherent and comprehensive psychophysiological account. He was willing to argue against aspects of Descartes' metaphysics in order to extend the explanatory power of psychophysiology, with respect to cerebral and mental processes and localisation, and particularly regarding memory as 'memory traces' imprinted in the brain. ${ }^{102}$ His account differs from Descartes in the following significant ways.

First, he denies Descartes' claim that we can have a clear and distinct idea of the soul, arguing that if Descartes truly had such an idea, he could easily discern its properties, just as he does concerning the nature of matter as

\footnotetext{
99 Malebranche 1674, II.i.5.i, in Malebranche 1997, p. 102.

100 Yolton 1983, p. 186, n. 8. To La Mettrie and Priestley we can add L'âme matérielle, as discussed in section 7 below.

101 Sutton 1998, p. 107. He cites psychologist William Burnham, who in 1888, after lamenting Descartes' "crude physiology" and "dogmatism," dubbed Malebranche "a true pioneer in the field of physiological psychology" for his account of brain traces and memory (Burnham 1888, in Sutton 1998, ibid.).

102 Malebranche 1674, II.i.5.ii, in Malebranche 1997, p. 105; ibid., II.ii.1, p. 135, and II.ii.4, p. 141. We do not aim here to give a genuinely detailed account of Malebranchian 'neurophysiology' (including memory and brain traces), which would include both Descartes and Louis de La Forge: for a masterful treatment see Sutton 1998, Chapter 3, Appendix 2, p. 106f.; for a more internal discussion of Malebranche's argument, see Kolesnik 2011.
} 
extension. ${ }^{103}$ The soul is distinct from the body, not because "the fact that I can clearly and distinctly understand one thing apart from another is enough to make me certain that the two things are distinct, since they are capable of being separated, at least by God,"104 but because the phenomenal features of our experience cannot belong to matter; they are excluded by its very nature. ${ }^{105}$ Defining the soul in this way allows Malebranche to be more equivocal (cautious?) about the soul than Descartes:

It is true that we know well enough through our consciousness, or the inner sensation we have of ourselves, that our soul is something of importance. But what we know of it might be almost nothing compared to what it is in itself. 106

And he recognises that our idea of the soul is not as clear as that which we have of the body. ${ }^{107}$

Malebranche's unwillingness to follow Descartes in his idea of the soul reflects a more cautious attitude regarding its derivation. He does not think God needed to give us a clear idea of the soul in order for it to perform its function united with the body, nor is a clear idea of the soul necessary for it to be revealed to us through faith. His emphasis on more experiential and functional aspects of the soul such as consciousness lent itself to later, materialist interpretations of its nature, as found in L'âme matérielle.

A further contribution to materialist interpretations of Malebranche's psychophysiology stems from his occasionalist metaphysics. Briefly, occasionalism is the doctrine that restricts causation to the will of God by denying the causal efficacy of all finite substances, whether material or immaterial. Malebranche takes this further in terms of psychological explanation by postulating the same type of causation for all occasional causes. In rendering physical and mental causation equally inefficacious, he is not subordinating one to the other. "He takes our inability to explain mental causation in the terms developed for bodily causation as an illustration not of the fundamental difference between the two sorts of substance but as an illustration of our ignorance of the mind." 108 LoLordo suggests that "there is no clear reason why one should place demands from the science of body onto explanations of the mind if, like Descartes, one views the mind as an entirely

\footnotetext{
103 Schmaltz 1994, p. 578.

${ }^{104}$ Descartes, Sixth Meditation, AT VII, 78, CSM, p. 54.

${ }_{105}$ Malebranche 1674, I.x.1, in Malebranche 1997, p. 49.

106 Malebranche 1674, III.ii.7.iv, in Malebranche 1997, p. 238.

${ }_{107}$ Malebranche 1674, III.ii.7.iv, in Malebranche 1997, p. 239.

108 LoLordo 2005, p. 398.
} 
different type of substance. There is no clear reason why a dualist should deny agency to the mind just because she denied it to body."109

Yet as with the idea of the soul, Malebranche exhibits a sort of intellectual caution here: he is unwilling to assume we have knowledge outside of what God furnishes us with for our own survival. Our knowledge of causation need not extend beyond our immediate experience and so he does not privilege one type of causation above another. There seems to be a dual commitment on his part: he is committed to God and has a priori theological justifications for a belief in the immaterial soul, but this same belief leads him to value the study of nature, and of the human being, as a study in and of itself. This emphasis on the functions and limits of the human being leads to a comprehensive psychophysiology that understands the knowledge we have of ourselves as nothing beyond what is necessary for our human environment.

All its [the soul's] sensations direct the soul to the preservation of its machine. They agitate the soul and frighten it as soon as the least spring is unwound or broken, and as a result the soul must be subject to the body as long as the body is subject to corruption. ${ }^{110}$

Malebranche's account of this preservation extends from the operation of reflex actions to the complexity of memory as distributed patterns of animal spirits in the brain, beginning from a basic description of nerve fibres: "they are composed of tiny filaments originating in the middle of the brain"; he has "reason to believe" that these nerve filaments are hollow, "like little canals," and "completely filled with animal spirits, especially when one is awake; when the end of these filaments is disturbed, the spirits contained in them transmit to the brain the vibrations they have received from without." $111 \mathrm{He}$ states later on that the soul "cannot impart movement to its body without animal spirits, and that it is through them that it recovers its control over the body."112 Malebranche elaborates on the relation between soul and animal spirits several times; most relevant to our emphasis on the strongly naturalistic, causal flavor of his analysis is this passage:

At the moment when the animal spirits are forced from the brain into the rest of the body to produce in it the motion appropriate to sustain passion, the soul is driven toward the

\footnotetext{
109 Ibid.

110 Malebranche 1674, III.i.1. ii., in Malebranche 1997, p. 200.

111 Malebranche 1674, I.x.2, in Malebranche 1997, pp. 49-50.

112 Malebranche 1674, II.i.V.4, in Malebranche 1997, p. 107.
} 
good it perceives, and the soul is the more driven as the spirits leave the brain with greater force because the same disturbance agitates the soul and the animal spirits. ${ }^{113}$

And the soul is localised: "these things clearly show that the soul immediately resides in that part of the brain to which all the sense organs lead" (I.x.3, p. 50; "to which the filaments of our nerves lead," I.x.5, p. 51). Of course, Malebranche introduces - not a caveat, not an argument-stopper, but a kind of token transcendental distinction: when he says it "resides there" (italics in original), he only means in the sense of a kind of awareness of what is occurring there (whether the action of the fibers or the reactions of the spirits within them); for "the soul can immediately reside only in ideas..." (ibid.). Later on, again in the midst of a swarm of naturalistic statements about the train of spirits, the mechanisms which produce ideas, and the fact that our sensations have to be related to our body, Malebranche again trots out a transcendental distinction (which in this case is mainly stipulative): "since ideas are spiritual, they cannot be produced from material images in the brain, with which they are incommensurable"; "a spiritual idea cannot be formed from a material substance" (III.ii.3, p. 223).

A more explicit version of the transcendental argument is given by Berkeley, who appears to be targeting precisely our set of authors, described as "they ... who hold the soul of man to be only a thin vital flame, or system of animal spirits," and thereby make the soul "perishing and corruptible as the body." Berkeley responds that it is "evident that bodies, of what frame or texture soever, are barely passive ideas in the mind, which is more distant and heterogeneous from them than light is from darkness," whereas

the soul is indivisible, incorporeal, unextended, and it is consequently incorruptible. Nothing can be plainer than that the motions, changes, decays, and dissolutions, which we hourly see befall natural bodies ...., cannot possibly affect an active, simple, uncompounded substance; such a being therefore is indissoluble by the force of nature ... the soul of man is naturally immortal. 114

Or, almost a hundred and fifty years earlier, in Timothie Bright's Treatise of Melancholie: "the soul hath a faculty one, single and essential," regardless of how many "parts are performed in the organical bodies." 115 If turn back to

\footnotetext{
113 Malebranche 1674, III.iii, in Malebranche 1997, p. 355.

114 Berkeley 1710, I, § 141 in Berkeley 1999, p. 87.

115 Bright 1586, ch. X, p. 44.
} 
Malebranche's psychophysiology, it becomes hard to miss the sheer weight of the naturalistic rather than the transcendental side of the analysis, and indeed it was the former that overwhelmingly predominated in the usage of Malebranche in the next generations - particularly in L'âme matérielle, as discussed below.

For he returns several times to the place of the soul's "residence," and adds an important theme which was present in Descartes but rather less overtly: that of our own physical self-preservation and survival. For the reason of the soul's location in the brain is "for the maintenance and preservation of all the parts of our body"; that is, it needs to be aware of the changes occurring in the body and to distinguish "those that are agreeable to our body's condition from those that are not" (I.x.5, p. 51). Curiously, Malebranche seems to hold that the existence of involuntary nervous processes which themselves are crucial to our self-preservation (such as blinking an eye, lifting one's arm to ward off a blow, or reacting to a burning coal placed in our hand while asleep ${ }^{116}$, are "very useful for the preservation of the body" but "extremely dangerous for the soul."117 On the one hand, sensations are key to our staying alive - to the preserving of our "machine," Malebranche says (machine was commonly used to mean 'body' in this period in French); but on the other hand, they render the soul "subject to the body," "they act upon the soul much more than the soul acts upon them."118

It is "the close union between soul and body" which both explains and obscures the nature of the human being; "which union prevents us from precisely distinguishing the properties of matter from those of mind."119 Despite or perhaps because of the coherence and comprehensiveness of his psychophysiological account, Malebranche does not make definitive claims about the nature of the human being. But the localisation or "residence" of the soul; the detailed account of how its activity relates to cerebral processes ("the soul can never sense anything or imagine anything anew unless these is some change in the fibers of this same part of the brain," II.i.1.i, p. 88), and the application of these concepts to human anthropology and psychology itself ("it is easy enough to explain all the different characters encountered among the minds of men, on the one hand by the abundance and scarcity, by the rapidity or slowness of agitation, and by the density or lightness of the animal spirits, and on the other hand by the delicacy or coarseness, the moistness and dryness, and the malleability of the brain fibers," II.i.1.iii, p. 89), makes for a

\footnotetext{
116 Malebranche 1674, III.i.1.iii, in Malebranche 1997, p. 201.

117 Malebranche 1674, II.i.5.i, in Malebranche 1997, p. 96.

118 Malebranche, op. cit., III.i.I.2, p. 200; II.i.5.i, p. 96.

${ }^{119}$ Malebranche 1674, I.x.6, in Malebranche 1997, p. 53.
} 
set of resources for materialism. These can be conceptual resources, but also, for an author of clandestine manuscripts in the early eighteenth century without access to the spheres of experimental natural philosophy, experimental ones: Malebranche had both demonstrated the need for knowledge of anatomy and provided some of that knowledge, referring for instance to Willis on arteries and cerebral anatomy. ${ }^{120}$

To be clear, Malebranche disagrees explicitly with the Epicurean tradition (represented in exactly the same years as the Recherche was published by the physician Guillaume Lamy, in his Discours anatomiques, and in the next generation by anonymous texts such as L'âme matérielle, discussed in sections 6 and 7 below; both Lamy and the anonymous author of L'âme matérielle also rely on Willis, Gassendi and earlier sources). The Epicurean approach seeks to materialise the soul by defining it, e.g. as a special kind of fire or wind, a position Henry More called 'Psychopyrism'121; Malebranche does not name names here but he recycles a Cartesian point that the soul can only be known by internal self-examination, and cannot be known via the mediation of any material entity like an "invisible fire" (III.i.1.iii, p. 202), which would be a category mistake.

But of course L'âme matérielle will ignore these counter-claims (which we have termed 'transcendental'), will retain the surprisingly detailed psychophysiology of nerve fibers, animal spirits and cerebral traces, ${ }^{122}$ and what appears to be a philosophical grounding of such descriptions:

The only alliance of mind and body known to us consists in a natural and mutual correspondence of the soul's thoughts with the brain traces, and of the soul's emotions with the movements of the animal spirits ${ }^{123}$

and will fuse it with precisely the Epicurean configurations of a material soul Malebranche sought to avoid. Put differently, the anonymous author uses a procedure that is typical of these manuscripts ('patchwork' [Thomson 2008], 'collage' [Bloch 2000], or 'cut and paste', etc.), and brings the Epicurean and Malebranchean analyses together, deliberately disregarding Malebranche's stated hostility to the former. ${ }^{124}$

\footnotetext{
120 Malebranche 1674, II.i.4.ii, in Malebranche 1997, pp. 89, 97; Kolesnik 2011. Willis is the only physician named or cited in Malebranche's enormous treatise.

121 Henry 1987, p. 34.

${ }^{122}$ L'Âme matérielle, 2003, pp. 200, 202, 234, reprising Malebranche 1674, II.i.5 and II.ii.1.

${ }^{123}$ Malebranche 1674, II.i.1.i, in Malebranche 1997, p. 102.

124 A less-known case is Bayle's appropriation of Malebranche's Méditations chrétiennes in a (paradoxical) Epicurean direction, analysed in Argaud 2009; other cases of deliberately
} 


\section{The material soul as "purest fire" and "subtle wind": Lamy}

We turn now to a self-proclaimed Epicurean, Guillaume Lamy (16441683), a philosopher and physician based in Paris, who received his medical degree in 1672 at Rouen and published his major works between the late 1660s and the late 1670s. Lamy aroused some fierce reactions: Bayle described him as an "over the top Epicurean" (un épicurien outré) and Haller simply stated he was an "impious man." 125

His first work, the 1669 De Principiis rerum, is an explicit piece of early modern Epicurean atomism, favouring Gassendi over Descartes (who was also viewed as a covert supporter of atomism), to show that Epicurus was right in the first place (although, in a gesture we will find often in works of this period, e.g. those of Cyrano de Bergerac, he also seeks to present these theories as complementary or compatible). He discusses atoms and the nature of matter, hesitating as to which theory he finds most convincing, but we shall chiefly focus on his medical-materialist approach to the soul. In De Principiis (I, v) and in his later works, the Discours anatomiques $\left(1675,2^{\text {nd }}\right.$ revised edition 1679) and the Explication méchanique et physique des fonctions de l'âme sensitive (1677), with which we shall be mainly concerned, he claims that the soul and animal spirits are actually identical. ${ }^{126}$ The functions of the soul are identified (a) with the nervous centres that receive impulses from external stimuli, and which ensure consciousness, ${ }^{127}$ (b) with the animal spirits which carry the "agitation" produced by the objects to the brain, which is the "source" or "reservoir" of the soul (pp. 152-153) , and then return to the heart, where they give rise to the passions, and to the muscles (which Lamy, following Galen, views as the instruments of voluntary motion). ${ }^{128}$ He verbally still maintains a difference between the sensitive soul and the rational soul but ultimately locates all of these distinctions within a physiological frame.

Chemical explanations (partly taken from Gassendi and Willis) play an important role here: muscular motion is explained as a kind of fermentation which, as we saw earlier, was a basic explanatory principle of vital processes

misreading Malebranche in the service of a new naturalistic scheme are surveyed in Kolesnik 2011.

125 Bayle, Nouvelles de la république des lettres (March 1684), art. II, p. 32, cit. in Mothu 19901991, p. 430; Haller 1774/1969, I, p. 556.

126 Discours anatomiques, in Lamy 1996, pp. 102, 105.

${ }^{127}$ Explication, in Lamy 1996, pp. 142-143, 160-161.

${ }^{128}$ Lamy also says - unlike Galen or Willis - that the soul "flows" from the brain like rivers flowing through the "canals" of the nerves (pp. 153, 160, 142). 
for Willis. Lamy has been described as a "discreet sympathiser with iatrochemistry," and in his Dissertation sur l'antimoine (1682) he describes himself as a "Chymist" as opposed to the "Galenists," and stresses that "Medicine owes a lot to chemistry."129

Lamy puts together Epicurean and Cartesian models deliberately (a synthesis which, in different forms - here, more medical, in other cases more focused on atomistic physics - was characteristic of a libertin intellectual and argumentative culture at the time, including Cyrano de Bergerac, Boyer $\mathrm{d}^{\prime}$ Argens and others, and extending beyond Lamy to clandestine texts such as L'âme matérielle, the better-known Treatise of the Three Impostors, 130 and the work of La Mettrie). He transposes Cartesian physiological analyses onto the issue of the soul, and by inquiring into the soul as a kind of substance, he inserts Epicurean content into these analyses. In addition, and this is also characteristic of libertin naturalistic thought, which is not 'science' but a programmatic naturalism, ${ }^{131}$ Lamy uses the concept of animal spirits to bind together these two theoretical schemas.

Lamy's modern editor, Anna Minerbi Belgrado, notes that the substantial interpretation of the soul also takes on another form in Lamy, that of the world soul, in a passage (itself using elements from Gassendi) which was taken over in different versions throughout the clandestine tradition and all the way to La Mettrie, as a materialist and atheist argument. ${ }^{132}$ The doctrine of the world soul of course allows of various interpretations, but here it serves an explicitly materialist purpose, in a faintly Spinozist sense given that it is an immanentist idea, implying that 'soul' is simply part of the material world (rather than something materialism would simply eliminate). An analogy with an amusing passage in d'Holbach's Le bon sens (1774) may shed some light on what this means.

\footnotetext{
${ }^{129}$ Mothu 1990-1991, p. 405 \& note 338.

130 The manuscript circulated in 1712, was printed once in 1719 and then in 1721 by Prosper Marchand and his friends; d'Holbach published an edition in 1777. The section which was known as L'esprit de Spinosa (and included the first French translation of a portion of Spinoza's Ethics) is today attributed to the Dutch diplomat Johan Vroesen (as Marchand indicated at the time), although this is sometimes contested, and another prime candidate for authorship is Jean-Maximilien Lucas (Israel 2001, p. 696).

131 For some indications as to the difference between the two in the 'radical Enlightenment', see Wolfe 2010.

132 Lamy, VIth Discourse, in Lamy 1996, p. 104f. This is the only passage in Lamy's work that will be taken over and discussed in the clandestine tradition (notably the Treatise of the Three Impostors, chs. XIX, XX and L'Âme matérielle, as discussed below), as well as by La Mettrie in his 1745 Histoire naturelle de l'âme (the revised version, entitled Traité de l'âme, appeared in 1750: see ch. VIII, in La Mettrie 1751, p. 104), and in the Encyclopédie's article "Âme."
} 
The material Jupiter of the Ancients could move, compose, destroy, and create beings similar to himself; but the God of modern theology is sterile. He can neither occupy any place in space, nor move matter, nor form a visible world, nor create men or gods. The metaphysical God is fit only to produce confusion, reveries, follies, and disputes. ${ }^{133}$

The analogy would be that the material soul is not an overt denial of the soul's existence but rather an affirmation of its corporeal existence, which, like the "material Jupiter," allows it to interact with other entities populating the material world; it is not ontologically unique, yet it lives and acts, just like a heart, a liver or a worm in the blood. An implication that was crucial at the time was that this unified and immanent material world implies the greater proximity of animal and human souls, a danger which Bayle saw: "the natural consequence of this dogma is to declare that the soul of animals is of the same nature as that of man." 134 Out of the myriad rather murky discussions of human and animal souls, their relative or fundamental differences, and the place of rationality, mortality and other key properties therein, Bayle saw most sharply that when a Pomponazzi or a Lamy reduces possible functional variations in "animal souls" to the "variety of organs and humours alone" (p. 104; Lamy's definition of an animal is simply "a mixture of humours and a particular structure of organs" ${ }^{135}$ ), his argument is in fact meant to apply to the human soul, which only differs from that of the animal in quantitative terms (only "une difference du plus au moins"136). Indeed, the later Treatise of the Three Impostors simply states, after a 'chimiatric' discussion of "subtle spirits" and the materiality of the soul, that "this soul [is] of the same nature in all animals." 137

Lamy observes, referring to Seneca, that "we all agree that we have a soul," but the difficulty lies in knowing what it is: some consider it to be a spirit, others a harmony between the parts of the body (a view he attributes to Galen amongst others, but Lamy notes that Galen is not entirely clear on the issue), a divine infusion, a "subtle wind," or an immaterial power. ${ }^{138}$ He then suggests the general distinction between the soul as incorporeal and as

\footnotetext{
${ }^{133}$ D'Holbach 1774, I, § xxiii, p. 24.

134 Bayle, "Rorarius," remark D, in Bayle 1740, vol. 4, p. 77.

${ }^{135}$ Lamy, VIth Discourse, in Lamy 1996, p. 106.

136 Bayle, "Dicéarque," remark L, in Bayle 1740, vol. 2, p. 287; "Rorarius," remark E, vol. 4, p. 79 and (as noted earlier), for the formulation "du plus au moins," the article "Péreira," remark E, vol. 3, p. 652 (see Paganini 1985 on the latter formulation).

137 1716/1904 edition, § VII, p. 99; 1768 edition, p. 85.

138 VIth Discourse, in Lamy 1996, p. 99.
} 
corporeal, and produces a rafter of arguments against the former view (including the perennial favourite: how could interaction take place?). Here we find a passage that was repeated in a number of other clandestine works, on the "subtle spirit" or very pure flame, and, as mentioned above, the "world soul". Lamy's adaptation and expansion of an old Epicurean motif served as a kind of resonance chamber for a number of radical, physiologically motivated, directed or influenced texts as late as La Mettrie's first writings on the soul (some seventy years later), which at that point can seem a bit archaic, as Thomson has noted. In the passage, which we cite below, we find, in addition to the phrase "world soul" or "soul of the world," several terms which functioned as quasi-technical terms in the period: "subtle spirit," "very fine matter," and "purest fire."

It is certain that there exists in the world a very subtle spirit or a very fine and always mobile matter, the greatest part of which and, so to speak the source, is in the sun, and the rest is distributed in all the other bodies, more or less, according to their nature and their consistency. It is certainly the soul of the world, which governs and enlivens it, and all of whose parts possess a portion of it. It is the purest fire in the universe, which does not burn of itself but, by the different movements which it gives to the particles of the other bodies in which it is enclosed, it burns and gives off heat. ${ }^{139}$

And in the version which appears in the Treatise of the Three Impostors:

It is certain that there is in the universe a very subtle spirit, or a very delicate matter, always in motion, the source of which is in the Sun, and the remainder is spread in all the other bodies, more or less, according to Nature or their consistency. That is the Soul of the Universe which governs and vivifies it, and of which some portion is distributed among all the parts that compose it. This Soul, and the most pure Fire which is in the universe does not burn of itself, but by the different movements that it gives to the particles of other bodies where it enters, it burns and reflects its heat. . . [T] his fire being enclosed in the body, it is rendered capable of thought, and that is what is called the soul, or what is called animal spirits, which are spread in all parts of the body. Now, it is certain that this soul being of the same nature in all animals, disperses at the death of man in the same manner as in other animals, from whence it follows that ... the other world is a chimera . . .140

139 Lamy, VIth Discourse, in Lamy 1996, p. 104; Thomson 2008, pp. 88, 160, 170.

140 (Anon.) 1716/1904, § VII, p. 99; (Anon.) 1768 edition, p. 85, emphasis ours. 
As will be developed much more extensively in L'âme matérielle, which we discuss below, the vital flame or "most pure fire" is equated here with animal spirits (once we are dealing with what is "enclosed in the body").

This is an ancient Hellenistic theme (found in Peripatetic, Epicurean and Stoic writings): human souls are not the only things in the universe that can be called souls, for "soul penetrates through the whole universe, and we by sharing in it, as a part, are ensouled."141 Epicureans writing after Epicurus added some layers of detail and complexity to the account he gave in the Letter to Herodotus, of the soul as a kind of wind, but also a kind of heat. For instance, Aëtius presents the Epicurean view as distinguishing between four elements which make up the soul: a fire-like one, an air-like one, a wind-like one, and an unnamed fourth element, which is responsible for sensation because of its particular fineness. ${ }^{142}$ Cardano considers the view that the soul is a kind of "celestial heat" to be Hippocrates' view - and a correct one. ${ }^{143}$ The Treatise of the Three Impostors compares Leucippus, Democritus, Hippocrates and Empedocles, who define the soul either strictly as a kind of flame, or as a combination of flame and other elements, to Epicurus, who also believes this, but adds "that in that composition there enters some air, a vapor, and another nameless substance of which is formed a very subtle spirit, which spreads through the body and which is called the soul."144 Walter Charleton, another early modern Epicurean (although one who has his spokesperson-character in one work declare that "as a Christian, I detest and utterly renounce the doctrine of that Sect, concerning Mens Souls," even if he is "an Epicurean, in many things concerning Bodies"145), also presents a description of the corporeal soul as "of Substance either Fiery, or merely resembling Fire; of a consistence most thin and subtile, not much unlike the flame of pure spirit of Wine, burning in a paper Lantern."146 As we have seen, thinkers including Malebranche and Berkeley denounced this concept, for its implicit or explicit materialism.

Briefly put, these images of 'subtle wind' or 'subtle spirit', 'very fine matter', fire or flame all convey the idea that the soul is composed of a special

\footnotetext{
141 Cleanthes apud Hermias, In Gent. Phil. 14 (Diels, Dox. Graec 654 [=svf 1.495]), in Annas 1992, p. 43.

142 Liddell-Scott frag. 14C, cit. Rapp 2006, p. 189. This is taken up and elaborated by Lucretius, De rerum natura, III, 262-265, 268-272.

143 "Hippocrates correctly said, the soul is nothing but the celestial heat" (De subtilitate, 5, cit. in Hirai 2011, p. 111). 
kind of matter. In Willis, this becomes a "subtle matter" which structures the body; this can be taken in an idealistic sense (thinking of Plato and Galen: the soul as the blueprint or 'form' of a substance) and in a materialistic sense (emphasised in anonymous treatises such as L'âme matérielle). But as regards the former, he is careful to distinguish his view from that of the "Soul of the Beast [as] an Incorporeal Substance, or Form." 147 And he is clearly committed to a new, chemically overdetermined concept of matter which is not "meerly passive" but active and self-moving. ${ }^{148}$ Gassendi also describes the soul as "a very tenuous substance, just like the flower of matter (flos totius materiae) with a special disposition, condition and symmetry holding among the crasser mass of the parts of the body." 149 It is a material soul, but with emergent properties, that are chiefly specified in chemical terms. As we will see in the next section, certain appropriations of the Lucretian motif that "the soul is to the body as scent is to incense"150 take this chemical-emergent sense one step further (towards materialism), by making the soul, no longer a material entity in its own right (whether in a humorally interactivist sense, a structural sense in which it teleologically orders the functioning of the body's organs, etc.) but a mere emanation or effluvium of a material substructure, the body.

\section{L'âme matérielle}

With the anonymous manuscript L'Âme Matérielle, ${ }^{151}$ which can be dated to approximately 1725-1730 based on some of its citations, we witness a first, and rather general programmatic attempt at the naturalisation of mental phenomena, that is, at locating mental phenomena within an integrated corporeal and cognitive scheme (the distinction between these two levels being both anachronistic and irrelevant here). ${ }^{152}$ Thanks to Niderst's research, we know that this text is an ingenious patchwork of Spinoza via Bayle (particularly his article "Buridan" in the Dictionnaire, the Pensées diverses sur la

\footnotetext{
147 Willis 1683, ch. I, p. 4.

148 Willis 1683, ch. VI, "Of the Science or Knowledge of Brutes," p. 33.

149 Gassendi, Syntagma, Pt. II, Physica, sect. I, Bk. IV, “De Principio Efficiente, seu de Causis Rerum," ch. 8, in Gassendi 1658, I, p. 337a; see also Garber 1998, p. 771.

150 "l'âme est au corps comme l'odeur à l'encens, l'un ne peut être détruit sans l'autre" (L'Âme matérielle, 2003, p. 174); as discussed below, this is a shorter, non-literal but more assertive rendition of Lucretius, De rerum natura III, 327-330.

151 Niderst first suggested Du Marsais as the author, who is now considered to have been the priest Etienne Guillaume (Mori and Mothu 2003), but this has been contested (Thomson 2008, p. 157, who does not say why). Guillaume was the author of, amongst other texts, De la conduite qu'un honnête homme doit garder pendant sa vie.

152 For further discussion of 'clandestine' strategies of naturalisation of the mind (including both L'âme matérielle and Fontenelle's earlier Traité de la liberté de l'âme) see Wolfe 2010.
} 
comète, but also the Réponse aux questions d'un provincial), Malebranche's psychophysiology, the doctrine of the (material) soul as a "fiery soul" from Gassendi as mediated through Bernier, Epicurean physiology (particularly borrowed from Lamy), travel narratives, and various materialist prodromes from Lucretius to Vanini and Hobbes, typically using the analyses and summaries given in anti-materialist works. Niderst comments, rather interpretively, that the anonymous author, handicapped by a lack of direct access to the sources, wanted to refute the "enemies" of materialism using the passages quoted in their own attacks! ${ }^{153}$ This has an effect on the physiological portions of the work, since they are based on older notions such as the "innate fire" in the soul, and animal spirits (which by the 1720s is no longer exactly state-of-the-art neurophysiology), to which the author adds the idea of cerebral traces as a basis for memory and association. Ideas are nothing other than traces in the brain, which are the impressions 'imprinted' via animal spirits by the effect of objects on our external sense organs. ${ }^{154}$

The argument for the materiality of the soul in this text has four basic elements: 155

(a) the predominantly Malebranchian account of animal spirits, blood and brain;

(b) the rejection of the difference between animal and human souls;

(c) mortalism, that is, the affirmation of the mortality of the soul;

(d) an Epicuro-Lucretian element, which conveys, however suggestively, the idea of an emergent-materialist conception of the soul.

(a) Materialist spirits

As noted earlier regarding Malebranche, this is a prime case of the way in which clandestine manuscripts appropriate a piece of a text and leave out the original author's protestations. Here, Malebranche's account of brain traces is taken on board, minus his denunciation of the idea. Recall that Malebranche did describe various cases of mind-brain identity: the "variety found in men's inclinations" depends on the "almost infinite variety found in the aural fibers, the blood and the spirits"; "the different characters encountered among the minds" can easily be explained "by the abundance

\footnotetext{
153 See Niderst's introduction to his new edition of L'Âme Matérielle, pp. 13, 16-17. For further discussion of this text see Vartanian 1982 and Thomson 2008.

${ }^{154}$ L'Âme matérielle, p. 200, 202, 234. Even the Jesuit Dictionnaire de Trévoux has under "Trace" a sub-heading entitled "Brain Traces" ("Traces du cerveau").

155 Our aim is not reiterate the presence of every single possible historical source, which in any case has been done by Niderst over the course of the three editions he has procured of the text (see also Mori and Mothu 2003 for additional sources).
} 
and scarcity, the rapidity or slowness of agitation, and by the density or lightness of the animal spirits, and . . by the malleability of the brain fibers; and finally, by the relation the animal spirits might have to these fibers." 156 This is so true that one can even "take the soul for a certain configuration of the parts of the brain, and for the motion of spirits." 157 But Malebranche sometimes warns the reader against trusting too literally in such an identity:

It is not enough merely to feel, or to have a vague understanding, that the brain traces are linked to each other, and are followed by movement of the animal spirits, that the traces aroused in the brain arouse ideas in the mind, and that the movements excited in the animal spirits excite passions in the will. It is necessary, as far as possible, to understand distinctly the cause of all these different connections, and especially the effects they are capable of producing. ${ }^{158}$

and above all,

It is true that there are some people stupid enough and others imaginative enough to constantly take the soul for a certain configuration of the parts of the brain, and for the motion of spirits... For what do we reply to a man who imagines that a desire, for example, is nothing but the movement of spirits; that a thought is but a trace or image of objects where spirits have formed in the brain; and that all reasonings of men consist only in the different placement of tiny bodies diversely arranged in the head? ${ }^{159}$

In contrast, the author of L'Âme matérielle is happy to assert as a kind of new, state-of-the-art physiological knowledge what Malebranche had declared to be the view of "stupid people":

The sense organs really act on the animal spirits . . . their action consist in pushing them into certain little canals rather than others. ... Hence we must treat the relation between the senses as material or, which is the same, as a mechanical action of the sense organs on the animal spirits, which I consider strictly as the most subtle parts of the blood and other bodily fluids, and as

\footnotetext{
156 Malebranche 1674, I.xiii.5, in Malebranche 1997, p. 64; Malebranche 1674, II.i.1, § 3, in Malebranche 1997, p. 89.

157 Malebranche 1674, VI.ii.7, § 3, in Malebranche 1997, p. 492.

158 Malebranche 1674, II.i.5, in Malebranche 1997, p. 101.

159 Malebranche 1674, VI.ii.7, § 3, in Malebranche 1997, p. 492, our emphasis.
} 
the rarefied and highly purified essence of the various matters which compose the human body. ${ }^{160}$

In addition, since memory is the preserving and renewing of this relation between the senses, it must be considered as material; memory is the "mechanics" of the process, formed by "material agents" (p. 230). This idea of the materiality of memory, the material traces of memory, is again Malebranchian:

For it is enough that many traces were produced at the same time for them all to rise again together. This is because the animal spirits, finding the path of all the traces made at the same time half open, continue on them since it is easier for them to travel those paths than through other parts of the brain. This is the cause of memory and of the bodily habits we share with the beasts. ${ }^{161}$

Or, as Kenelm Digby had put it some decades earlier: "there is no act of our soul, without speculation of phantasms residing in our memory." 162 When we have referred to the medicalisation (a more specific historically specifiable process) and naturalisation (a more conceptual process) of the soul, we meant that this was not identical with a reduction of higher-level features (mind, intentionality, consciousness ...) to the basic features of matter, or basic physics (whatever that might mean in this period). An indication of this is the usage here of the animal spirits concept and how it allows for a material account of memory and association of ideas, which can account for our immense capacity for memory, but also for the alteration and confusion of our memories. For memory is defined here as a set of inextricable connections between brain traces made by the flow of spirits, such that "none can be aroused without all those which were imprinted at the same time being aroused."163

Further, the manuscript also draws reductionist consequences from this psychophysiology, in the sense that our mental life is physiologically dependent on, and constituted by the movement of the animal spirits, and thus, in a separate claim (which is also characteristic of this tradition), we are

\footnotetext{
160 L'âme matérielle, 2003, p. 230. Malebranche also defined life in terms of blood: "man's life consists only in the circulation of the blood" (Malebranche 1674, II.1.i, in Malebranche 1997, p. 90).

161 Malebranche 1674, II.i.5.ii, in Malebranche 1997, p. 106.

162 Digby, The Nature and Operations of Man's Soule, ch. X, in Digby 1645, p. 96 (the two treatises are printed together but paginated separately).

163 Malebranche 1674, II.i.5.ii, in Malebranche 1997, p. 105.
} 
not free: "Can man interrupt the emotions of spirits and blood, or the perturbations of the brain, precipitated by [external] objects? ... Our happiness, wisdom and freedom are dependent on the motion of the animal spirits which we do not control, and these motions ... cause the emotions in our soul. None of this is free, nor can it be prevented." 164 The animal spirits doctrine is taken in a further 'immoralist' direction to mean that the composition of our blood determines us to virtue or vice, a motif which, as we saw, led the surgeon Timothie Bright to warn of the dangers of blurring the boundaries between soul and body, and which La Mettrie will happily and thus scandalously reprise (Wolfe 2009). ${ }^{165}$ God cannot judge us, because our inclinations and acts are the effect of the movement of the animal spirits: "Natural inclinations are continuous impressions of the motions of animal spirits. We are not free ... ; we do not have the power to love or not to love, and God cannot make this a crime. ${ }^{166}$

What befalls the soul, then? What is the concept of the material soul articulated in a treatise entitled ... The Material Soul? The text began by stating that the ancients, with the exception of the Pythagoreans and the Platonists, denied that there was a difference between the human soul and matter - not vile, low, palpable matter but "matter as understood by the chemists," i.e. matter with active properties such as animal spirits - yet matter which is "as essentially bodily and material as mud and flesh can be." 167 Further on we hear of various ancient authorities who also held the soul to be corporeal (pp. 34-48). The problem of the soul and the human mind (l'esprit de l'homme) is one of the most difficult ones there is in philosophy; in order to know it well, one needs to be "well versed in anatomy," and have "in-depth knowledge of our body's machine" (p. 172), on which no one is a better source than "Father Malebranche" (on the brain and animal spirits ${ }^{168}$ ) - except that the text continues with a long excerpt (pasted in as it were, according to a method of collage which is characteristic of the clandestine manuscripts) from Lamy's Discours, on the world-soul and 'animal chemistry', which includes the reference to the Lucretian image that the soul is to the body as scent is to incense.

As noted, there are four basic points supporting the idea of the materiality of the soul here, of which we have discussed the first. We now

\footnotetext{
164 L'Âme Matérielle, 2003, p. 182 (cf. Malebranche 1997, V.i.4), emphasis ours.

165 L'Âme Matérielle, 2003, p. 178.

166 Ibid., p. 176.

167 L'Âme Matérielle, 2003, p. 34.

168 The text glosses on the brain and animal spirits, essentially based on Malebranche, at pp. 190-220.
} 
turn briefly to the second and third elements, before focusing more fully on the fourth, which is of greater relevance to our analysis - it is perhaps the most original part of the text (including in the way it is articulated together with the brain and animal spirits theme), and, again, the most explicitly Epicurean.

\section{(b) Animal and human souls}

The author argues that there is no inherent or metaphysical difference between animal souls and human souls, with texts partly taken from Montaigne and Bayle (and Dilly to a larger extent). ${ }^{169}$ Similarly, a parallel is suggested between the fact that human cognitive abilities vary, as they are affected by early childhood development, language acquisition, etc. (examples include 'wild children' from Poland and Borneo and the deaf and mute boy from Chartres), and the fact that animal cognitive abilities are also not uniform, especially in the absence of education (pp. 88-90), a point that will be made quite forcefully by La Mettrie and others with the "discovery" of the "orang-outang." A faintly Spinozist point is made that if our "soul" (or mind) were attached to a different body, whether a less sophisticated body such as that of an animal or a body with more potential than ours, its abilities would be correspondingly affected (pp. 94-96). The Cartesian conception of animalmachines is challenged by appealing to various descriptions of animal emotions, loyalty, intelligence, etc. ${ }^{170}$

\section{(c) The mortality of the soul}

The text presents a case for the mortality of the soul, and replies to objections against it (chapters II, IV). The author identifies 'body' and 'substance' as bearers of properties, as substrates of change; hence the term 'incorporeal substance' is a "frivolous" term, internally contradictory (p. 54). Also included are a series of familiar arguments against the non-locality or non-spatiality of the soul (pp. 68-70), familiar from Hobbes. After some discussion of the soul, the author employs an idea that was much discussed in radical journals such as the Nouvelles de la république des lettres, in the wake of Locke's Essay: not just thinking matter per se but the specific insight (which would be popular in dissenting texts all the way to Joseph Priestley ${ }^{171}$ ) that

\footnotetext{
169 Recall Bayle's comment in the article "Pereira," remark E that "On ne devoit point penser que l'âme des bêtes et celle de l'homme différassent autrement que du plus au moins ..., et par conséquent on a dû croire que la seule disposition des organes est cause" (Bayle 1740, vol. 3, p. 652).

${ }^{170}$ L'âme matérielle, 2003, pp. 96-106, with more details supplied after the criticism of Descartes, pp. 106-122, including an elegant combination of Bayle and Lahontan on beavers. 171 Priestley 1778, pp. xvi-xviii; Thomson 2008, pp. 223-224.
} 
nothing in Scripture prevents God from having "superadded" thought, or the capacity of thought, to matter, such that Cartesian substance dualism is revealed to be a philosophical construct rather than anything either (a) obviously true or (b) expressing the true content of Scripture (p. 144). In Locke's own words,

we shall never be able to know, whether any mere material Being thinks, or no; it being impossible for us, by the mere contemplation of our own Ideas, without revelation, to discover, whether Omnipotency has not given to some Systems of Matter fitly disposed, a power to perceive and think, or else joined and fixed to Matter so disposed, a thinking immaterial Substance. ${ }^{172}$

\section{(d)Psychopyrism, or the Epicurean pyrotechnics of the soul}

We have encountered, both positively, in Lamy and the Treatise of the Three Impostors, and negatively, in Malebranche's and Berkeley's criticisms, the doctrine of the soul as a type of 'wind' or 'flame' - which Henry More attacked as 'Psychopyrism' ${ }^{173}$ Where Willis was only trying to bring together chemistry, anatomy and physiology to produce an integrated model of brain function and cognitive processes (without materialist intentions), the clandestine texts, including L'Âme matérielle, turn this claim that the soul is both like a flame, and also "formed of the most subtle parts of the blood," into an explicit materialist claim: "man's soul is material." ${ }^{174}$ In that sense it was quite fair for Thomas Browne to describe the Treatise of the Three Impostors (chapter V of which is "On the soul") as being written by a "villain and secretary of hell." 175

L'âme matérielle brings together in a few sentences, the motif of the soul as a "little flame," and Gassendi's motif of the "flower of matter." 176 He had described the soul as "a very tenuous substance, just like the flower of matter (flos totius materiae) with a special disposition, condition and symmetry holding among the crasser mass of the parts of the body."177 One can see a trend from Gassendi and Bernier through Willis, Lamy and now the early

\footnotetext{
172 Locke 1975, IV.iii.6, pp. 540-541.

173 Henry 1987, p. 34.

174 Lamy, VIth Discourse, in Lamy 1996, p. 104; L'Âme matérielle, 2003, p. 172 (the soul as flame), p. 228 ("l'âme de l'homme est matérielle").

175 Browne 1892, § XX, p. 44.

176 L'Âme matérielle, 2003, pp. 174, 175.

177 Gassendi, Syntagma, Pt. II, Physica, sect. I, Bk. IV, “De Principio Efficiente, seu de Causis Rerum," ch. 8, in Gassendi 1658, I, p. 337a (see also Garber 1998, p. 771); also in Bernier 1678, V, book VI, ch. iii, p. 456.
} 
eighteenth-century clandestine texts such as L'âme matérielle, from a chemical conception of Life and a differentiation of types of soul, to a materialist attitude in which the soul is a mere emanation or effluvium of a material substructure, the body - a "flower of matter."

More explicit yet is L'âme matérielle's brilliant and elegant rendition of a passage from Lucretius (in fact, the author is using de Coutures' translation of De rerum natura, which went through many editions between 1680 and 1720). Here, the passage becomes "the soul is to the body as scent is to incense."178 This is more direct than the original, which describes the bond between soul and body as a mutual guardianship, in which the soul is the cause of the body's life; and then uses the image of scent and pieces of incense: just as one cannot tear the scent out of the pieces of incense, one cannot tear the (nature of) animus or anima, mind or soul from the body, without the whole dissolving. ${ }^{179}$ It is an intriguing image, because it simultaneously reduces the soul to a derivative, dependent feature or product of a corporeal, material entity - the body - and also ensures that the soul is part of the province of a medicalised natural philosophy (rather than denying its existence outright). The same idea is conveyed by Willis in an equally emergentist image, which he credits to Lucretius via Gassendi: "the Animal is as it were the Loom, in which the Yarn is the Body, and the Woof the Soul." 180 A hard-boiled, reductive materialist faced with such ideas might respond that here, "we no longer really know if we are materialising the soul or animating matter."181 But that is the historical reality one has to deal with, once thinkers are no longer invoking a Cartesian distinction between thought and extension, or the metaphysical specificity of the rational and free human soul, or when such conceptual schemes are never invoked; and it only becomes more complicated in the eighteenth century, with the added focus on the (material, corporeal)

\footnotetext{
178 "L'âme est au corps comme l'odeur à l'encens, l'un ne peut être détruit sans l'autre" (L'Âme matérielle, 2003, p. 174). The author is apparently using de Coutures' translation of Lucretius, De rerum natura III, 327-330 (Niderst 2003, p. 60, n. 1). In the 1692 edition, the passage is at p. 411. It is also discussed by Gassendi in the Syntagma (in the chapter on the soul, Pt. II, Physica, sect. 3, membrum posterium, Bk. III, "De Anima," ch. 2, "Qui animam corpoream fecerint?", in Gassendi 1658, II, p. 249b; thanks to Delphine Bellis for helping locate this citation), and in the Theophrastus redivivus.

179 "Quod genus e thuris glaebis euellere odorem / haud facile est, quin intereat natura quoque eius / sic animi atque animae naturam corpore toto / extrahere haut facile est, quin omnia dissoluantur / Implexis ita principiis ab origine prima / inter se fiunt consorti praedita uita" (Lucretius, De rerum natura III, 327-329, emphasis ours).

180 Willis 1683, ch. I, p. 2.

181 Canguilhem 1977, p. 86.
} 
properties of irritability and sensitivity as intentional properties, replacing traditional conceptions of the soul as the 'pilot in the ship'. ${ }^{182}$

Both Lamy, invoking a medical Epicurean conceptual framework, and the author of L'âme matérielle, working with a smorgasbord of elements both contemporary and ancient (and often removed from their own intended theoretical context, like the portions of Malebranche on the brain and animal spirits) are articulating a concept of soul as something material. We cannot be more ontologically precise than the texts themselves - thus for instance it is difficult to decide if the material soul here is an actual structure, something fully corporeal or organic, or if it is an emergent property of such a structure, as the incense image seems to indicate. However, the relation between scent and incense is a classic case of a relation between secondary and primary qualities, itself quite at home in a mechanistic framework (but that would be another paper).

L'âme matérielle speaks quite explicitly of the "materiality of the soul" (p. 222), uses the argument (which La Mettrie will expand on considerably, especially in L'Homme-Machine) that states of disease are evidence for the interaction of soul and body - and further, that they establish that both are composed of one and the same substance (p. 56), such that "the mind is subject to the law of all corporeal beings" (ibid.). We are also told in the last sentence of the treatise (p. 236) that it is the "matter of which the brain is composed" that thinks. But even if the soul is material, the ontological status of this materiality is not generic: "The human soul is material, and is made up of the most subtle parts of the blood" (p. 228). To use a distinction suggested by Wright (Wright 2000), but in a different sense from him, we can say that the soul as locus of mental activity is here being conceptualised both as substance - as a material substance subject to physical and biological laws and as function - belonging to medicine in general and medicina mentis in particular. ${ }^{183}$

Of course, the objection made by Malebranche and others down to Kant (who insisted contra Soemmerring that one had to distinguish between

\footnotetext{
182 On sensitivity (sensibility) and irritability as properties of matter in the eighteenth century see Wolfe forthcoming 2013.

183 On the naturalisation of the soul as 'substance' or as 'function', see Vartanian 1982 and Wright 2000; on the ontologically neutral aspect of this naturalisation, Hatfield 1995, pp.188, 191. Vartanian comments usefully that "if one conceives of the soul as the effect or function as certain structures of organised matter, it is inevitable that the more legitimate articulation of such a concept occurs through the progress of knowledge regarding anatomical structures themselves, and their modes of operation" (Vartanian 1982, pp. 159-160).
} 
the 'seat of the soul' and the 'seat of the organ of the soul')184, that there is a category mistake being made (with dangerous consequences, moral and other) when one allows for the medicalisation of the category of soul is - not logically refuted here, but rendered practically inert, as is also apparent in the popularity of the concept of soul as a 'heuristic' in early localisationist neuroscience. To be precise, one can either deny the very possibility of localisation (as Henry More did explicitly; Henry 1989, pp. 100-101), be 'agnostic 'or 'functionalist' on the issue (like Malebranche), claim to have localised and materialised the soul, or present it as a functional property of a particular arrangement of matter ("the most subtle parts of the blood," "the flower of matter," etc.). The latter two perspectives reflect a tension between models of the materialist soul - not between Epicurean and other models, but within Epicureanism, where the soul is alternatively conceived, to speak formulaically, as a kind of substance or as the effect of a kind of substance.

The final historical episode we examine is an explicit outgrowth of the ideas surveyed in the previous sections, particularly Lamy and L'âme matérielle. A notable difference is that whereas the latter texts blur genres without self-consciously defining a genre, materialists such as La Mettrie and Diderot are self-conscious, both in defining themselves as as such (La Mettrie is the first recorded author to describe himself as a materialist ${ }^{185}$ ), and in using medical arguments in support of naturalistic philosophical positions.

\section{Materialism and the soul's remainder: La Mettrie and Diderot}

The question of the soul is approached in various ways within the materialist context. As noted, with thinkers such as Julien Offray de La Mettrie (1709-1751) and Denis Diderot (1713-1784) in the mid-eighteenth century, we are dealing with an intellectual context that is significantly influenced by the Epicurean and more generally heterodox traditions we have been discussing. La Mettrie himself changes his view on the soul, as Ann Thomson has noted; he changes - both in his revision of his 1745 Histoire naturelle de l'âme to the 1750 Traité de l'âme, and in his move from the work on the soul to L'Homme-Machine in 1748 - from a more Epicurean view of a "fiery soul" (à la Lamy) to a model we would more immediately recognise as materialist, in which thought is the emergent property of the material

\footnotetext{
${ }^{184}$ As late as the 1790s, the anatomist Samuel Thomas Soemmerring decided that the cerebrospinal fluid (fluid of the brain cavity) was the locus of the sensorium commune, and decided to locate the soul there. For Kant's attack on Soemmering, see Hagner 1992, p. 9.

185 The term 'materialist' is used - pejoratively, but in the sense we would recognise today by Henry More in the 1660s, in English, and by around 1700 by Leibniz in French (although earlier occurrences have been found in the previous decades). See Bloch 1995.
} 
arrangement of the brain. ${ }^{186}$ But as we have seen earlier, even within the Epicurean tradition, both of these views exist: a fully substantivalist view of soul in material terms, and a reductionist view which makes soul, if it exists at all, a functional property of a particular material arrangement.

More interesting to us is that this shift can also be seen in broader terms as a shift within reductionist strategies, which we can also classify as types of reduction.

There is the classic, full-scale reductionist approach, which might be most familiar to a modern reader. This can vary from La Mettrie's "s/ he who wishes to know the properties of the soul must first search for those which manifest themselves clearly in the body"187 (which, one may notice, is not a statement that there is no such thing as the soul, but rather the advice to start with the body), to hard-line denials, such as the dismissive comment in the article "Physiologie" in the Encyclopédie: "If the body is healed, one need not worry about the soul." 188 Or La Mettrie himself: "The soul is just a pointless term of which we have no idea and which a good mind should only use to refer to that part of us which thinks." 189 In this case, soul is being reconstrued as a functional definition: it is neither eliminated in favour of a hypothetical 'basic physics' or the properties of matter in general, nor asserted as unique in its own right. But more often, in this type of reduction we find either (a) the weaker denial that the soul could be relevant at all to medicine, as in Ménuret's statement we discussed earlier, that the soul is not "based on any medical observation; hence we will ... restrict ourselves to describing the changes of the body," 190 or (b) a stronger denial that there is no such thing, period, as in d'Holbach:

You speak of your soul but do you know what a soul is? Can't you see that this soul is merely the assemblage of your organs, from which life results? Would you then deny a soul to other animals, who live, think, judge, and compare, like you; who seek pleasure, and avoid pain, like you; and who often have organs, which serve them better than yours do? ${ }^{191}$

\footnotetext{
186 Thomson 2008, p. 188. This change does not prevent La Mettrie from being an Epicurean in a very thoroughgoing sense, both in his medical materialism and in his hedonistic ethics (Wolfe 2009).

${ }^{187}$ Traité de l'âme, ch. I, in La Mettrie 1751, p. 86.

188 (Rather loosely rendering "Qui a guéri le corps, ne doit pas s'inquiéter de l'âme" ;

"Physiologie," 1765, p. 538a).

189 La Mettrie 1751, p. 54; La Mettrie 1960, p. 180.

190 Ménuret de Chambaud 1765/1966, p. 718b.

191 D'Holbach 1774, I, XCIV, p. 92.
} 
Sometimes this hard-line denial of the soul forgoes the polemical tone and turns wholly instrumental, as in Maupertuis' project of "modifying the soul" by administering drugs. Maupertuis, the Secretary of the Berlin Academy of Sciences in the mid-eighteenth century, proposed, using a rather odd term, that "metaphysical experiments" (expériences métaphysiques) be carried out to "modify the soul," by chemically altering mental states:

Might we not find here the art of producing dreams? Opium usually fills the mind with agreeable images; greater wonders yet are spoken of, concerning certain beverages of the Indies . . . There may be other means still, to modify the soul. ${ }^{192}$

Clearly here 'soul' is a functional, material category, not one half of a dualist pair. Qua functional entity, the soul can be defined by the materialist as a term we "should only use to refer to that part of us which thinks" (La Mettrie), or as a "modifiable," manipulable entity (Maupertuis). A locus of cognitive functions which has been so thoroughly naturalised that it is open to manipulation is, of course, rather like 'mind' from the psychologist's point of view, something Lamy casually points to when he says "I used the words soul and mind interchangeably ... because they are the same thing."193

But it is also possible for the materialist to be less overtly confrontational towards the concept of soul. Either because it has been naturalised, including through its reconfiguration in a medical tradition (be it Aristotelian-Averroist, Galenic-humoral, post-Cartesian or Epicurean); in that case the soul can be treated, La Mettrie suggests, as

but a principle of motion or a material and sensible part of the brain, which can be regarded without fear of error as the mainspring (ressort) of the whole machine, which visibly influences all the other [springs], and seems indeed to have been made first, so that all the other parts are but a kind of emanation from the brain. ${ }^{194}$

A material and sensible part, a spring - albeit a special, particularly foundational spring within the workings of the overall corporeal machine and one which is located in the brain. Here, as in Diderot, the status of the soul is displaced away from metaphysics towards the particular case of the

\footnotetext{
192 Maupertuis, Lettres sur le progrès des sciences (1752), in Maupertuis 1768/1967, vol. II, p. 426. ${ }^{193}$ Lamy, Explication, ch. VII (conclusion), in Lamy 1996, p. 176. He adds, in a rather archaicsounding technical flourish, that he is using 'mind' primarily for "the portion of the Soul contained in the nerves," and 'soul' for the "spirits contained in the brain" (ibid.).

${ }_{194}$ La Mettrie 1751, p. 63 / La Mettrie 1960, p. 186.
} 
brain. ${ }^{195}$ La Mettrie also recasts the soul as a kind of complex mechanism, or mechanistically specifiable force, in a dense comment which is partly a respectful criticism of Willis and the anatomist Claude Perrault:

Willis and Perrault, minds of a more feeble stamp, but careful observers of nature ... seem to have preferred to suppose a soul generally extended over the whole body, instead of the principle which we are describing. But according to this hypothesis (which was that of Virgil and of all Epicureans, a hypothesis which the case (histoire) of the polyp might seem at first sight to favor), the movements which go on after the death of the subject in which they inhere are due to a remnant of soul (reste d'âme) still maintained by the parts that contract, though, from the moment of death, these are not irritated by the blood and spirits. Whence it may be seen that these writers, whose solid works easily eclipse all philosophic fables, are deceived only in the manner of those who have endowed matter with the faculty of thinking. I mean to say, by having expressed themselves badly in obscure and meaningless terms. Indeed, what is this remnant of a soul, if it is not the "motive force" of the Leibnizians . . ., which however Perrault in particular has really foreseen. ${ }^{196}$

First, we are told that an Epicurean "hypothesis" of a 'residual soul' or a "remainder of the soul" dispersed in the body, is not quite correct (and La Mettrie had entertained more such views in his earlier work). Second, which complicates matters considerably, we are told that this hypothesis is akin methodologically? - to that according to which matter can think, i.e. the core materialist hypothesis. ${ }^{197}$ But in any case, his third point is that this "remnant" is like motive force - in other words, nothing supernatural, nothing immortal or immaterial; a natural function.

However, the materialist approach to the soul discussed here, inasmuch as it partly reflects the early modern Epicurean context (whether

\footnotetext{
${ }^{195}$ Diderot's late Eléments de physiologie, as well as his supplementary remarks in the Encyclopédie article "Âme," stress both the complexity of the brain for any reductionist materialist project, and the 'displacement' of the soul therein.

${ }_{196}$ La Mettrie 1751, pp. 66-67 / La Mettrie 1960, p. 188, emphasis ours.

${ }^{197}$ At the beginning of the book, La Mettrie had addressed the claim that matter can think, and instead of coming out for or against it, he stripped the claim of some of its incendiary character, and proposed the analogy between matter being able to think, and matter being able to tell time (La Mettrie 1751, p. 9 / La Mettrie 1960, p. 150). This is actually a somewhat mysterious analogy which may simply be addressing how the functional properties of different material systems, differ accordingly: thought for the brain, time-telling for watches and clocks. This implies that La Mettrie could also actually be agreeing with the view - i.e., that the "remnant of soul" hypothesis is like the thinking matter hypothesis, which he had subtly endorsed at the beginning of his book.
} 
this is viewed as archaic or not), remains an embodied approach - which is partly reflected in La Mettrie's rather surprising choice of the case of the polyp as further illustration of a "remnant of soul": the polyp's capacity to live in seccated forms implies that there is no central soul but rather a principle of animation dispersed throughout the body. ${ }^{198}$ Put differently, the concept of the body which is at work in these materialist texts is, if not 'ensouled', certainly animated and vitalised, as in this remark of Diderot's:

Whatever idea we initially have of [the soul], it is necessarily a mobile, extended, sensitive and composite entity. It grows tired just like the body, it rests like the body, it loses its control over the body just as the body loses its control over the soul. . . Is the soul gay, sad, angry, tender, shy, lustful? It is nothing without the body. 199

Even when La Mettrie is at his most reductionist, he speaks of soul and body as "correlative" ("the various states of the soul are always correlative with those of the body"200), although when he tries to describe mutual limitation it does not sound so symmetrical: "nothing is as limited as the empire of the soul over the body, nothing so extended as the empire of the body over the soul." 201

Ultimately, whether these forms of reduction are weak or strong, coherent or wavering, they do not reduce the soul to matter in motion, or to inanimate atoms. When Diderot, in his commentary on Franz Hemsterhuis' 1772 Lettre sur l'homme, writes "wherever I read soul I replace it with man or animal," 202 he is encapsulating in a phrase a process of conceptual crystallisation we have been following in the previous sections. It is both a medicalisation of metaphysics, in the sense that medical knowledge and observation are allowed to modify metaphysical claims, ${ }^{203}$ and - partly due to this specifically medical context - a reduction to body: "the action of the soul on the body is the action of one part of the body on another, and the action of

\footnotetext{
198 Antoine-Martin Roche, in his 1759 Traité de la nature de l'âme, et de l'origine de ses connoissances. Contre le système de Mr. Locke $\mathcal{E}$ ses partisans, distinguishes between two materialist views of the soul, a 'Spinozist' view according to which the soul is coextensive with the entire body, and a 'materialist' view according to which it is just material per se (discussed in Yolton 1987, p. 90f.). La Mettrie's usage of the example of the polyp here would be a prime case of the first.

199 Éléments de physiologie, in Diderot 1975-, XVII, p. 334.

${ }^{200}$ La Mettrie 1751, p. 22 / La Mettrie 1960, p. 158.

${ }^{201}$ La Mettrie, Traité de l'âme, ch. XII, § 2, in La Mettrie 1751, p. 155.

${ }^{202}$ Hemsterhuis / Diderot 1772/1964, p. 277.

${ }^{203}$ A process we have traced back as far as the reception of Aristotelian natural philosophy and the emergence of humoralism, both in the sixteenth century.
} 
the body on the soul is again that of one part of the body on another" 204 (Diderot again).

It is not just, as we argued in earlier sections, that medical debates are relevant to thinking about the soul. They also have an impact on the philosophically specific positions taken (whether as specifically medical approaches to body-soul relations, as in Boerhaave, Gaub, Cullen or Le Camus, or as deliberate syntheses of medicine and philosophy, as in Lamy or L'âme matérielle). The specifically medical flavour of the materialism we see here - which is also Epicurean - means that its reductionism is a reduction to body. Conversely, that these thinkers are materialists, and committed to a reductionist program, distinguishes them from other complex cases of the blending of medicine and metaphysics (such as Glisson). ${ }^{205}$ But, as Willis stressed following Gassendi, the type of matter that is at issue here is not "meerly passive": it is not the brutish matter, "lacking action, sentiment or any intelligence ... the most vile of beings," which apologeticists tended to portray it as. ${ }^{206}$

This specifically medical materialism is a materialism of fluids, affects, and spirits; it is humoralist, Epicurean and chimiatric, amongst other elements which compose it. In that sense, the material soul concept(s) as presented here show that materialists are not "merchants of vanishing" (Sutton and Tribble forthcoming). But what is its posterity? Diderot in his late manuscript on 'physiology' and its conceptual ramifications imagines what he calls a "physical medicine": since "every sensation and every affection is corporeal, it follows that there is a physical medicine which is equally applicable to the body and the soul." 207 It is not clear what exactly this "physical medicine" might be (Rey 2000 suggests it would be more organismic, less reductive), but it hints (as does Le Camus with less philosophical sophistication) at the emergence of a scientific psychology - at a naturalisation of mental phenomena and beyond, which is quantitative and experimental (considering the role of poisons and hallucinogens, the organic dimensions of mental illness, and so on), and at the same time is squarely focused on an embodied, non-abstract type of consequence: "That the mind possesses such a corporeal nature need not be feared as a blow to our self-esteem" (La Mettrie 1747, p. 111).

\footnotetext{
204 Éléments de physiologie, in Diderot 1975-, XVII, pp. 334-335.

205 On Glisson in this context, see Henry 1987 and Giglioni 2008. On how an Epicurean medical context produces a uniquely embodied form of reductionism, see Wolfe 2009 (on La Mettrie) and Wolfe 2012a (more generally).

${ }^{206}$ Denesle 1765, I, pp. 32-33, note a, and p. 90.

207 Diderot 1975-, vol. XVII, p. 512.
} 


\section{Conclusion}

We hope to have shown that the concept of material soul is neither reducible to a series of "confusions or contaminations between notions of spiritus, pneuma, and anima," 208 nor a kind of archaic remainder which gradually vanishes with the emergence of physiology after Haller in the later eighteenth century. Granted, from the standpoint of history of science, it should be construed as just that - after all, it is hard to build a scientific psychology on "subtle winds," humours or animal spirits, and it is not even necessary to make an ontological commitment to materialism: "no one bothered to tell the early practitioners of natural scientific psychology that they had to be materialists in order to be natural scientific psychologists. In point of fact, of all the major eighteenth-century authors who made contributions to the development of psychology, only Erasmus Darwin allowed that mind might be material." 209

But it would be absurd to judge Lamy, Malebranche, La Mettrie or L'âme matérielle as way stations between Aristotle's doctrine of the soul and faculty psychology (or rather, the emergence of experimental psychology in the nineteenth century). What they are (making an exception for the Oratorian Malebranche who would be unhappy to be presented as a fellow-traveller of materialism), aside from fascinating documents of intellectual history, or exemplars of the Radical Enlightenment, are crucial episodes in the articulation of materialism and the soul understood as the locus of mental processes - not just in a restricted sense in which they would be part of a family of early modern materialist theories like Hobbes's or d'Holbach's. Rather, as we have emphasised, they are outgrowths of an Epicurean tradition which is closely interlinked with a medicalised approach to natural philosophy: they present an embodied, humoral materialism, in which "the human soul is material, and is made up of the most subtle parts of the blood" (L'Âme matérielle, p. 228); a "flower of matter," as Gassendi put it.

The presence of these citations as motifs at the heart of the early modern Epicurean vision of the material soul does indeed seem to be a far cry from the history of medicine. Indeed, Lamy's contribution has been judged to be "a rather literary brand of medicine, overall." ${ }^{210}$ But this materialism of

\footnotetext{
${ }^{208}$ Henry 1987, p. 23 (reprising a point made in Walker 1984).

${ }^{209}$ Hatfield 1995, p. 217.

210 Bloch 1992, p. 79.
} 
animal spirits and humours is unique in its embodied character: neither a crude mechanistic materialism in which matter is "meerly passive" (Willis) ${ }^{211}$ (since if we treat matter as merely possessing the properties of "solidity, inertness, or sluggishness," we can then, as Priestley saw, only "derive ... from this circumstance [its] baseness and imperfection"212) nor an idealism in which Life is entirely the immaterial life of the soul, as it might have been for Ralph Cudworth or Henry More. And this uniquely embodied character stems primarily from the medical context.

That the view described here is sometimes called Spinozist (aside from opprobrium, which is not our concern) is intriguing, given that nowhere in Spinoza is there any kind of 'biologistic' or 'embodied' emphasis on living beings as possessed of a unique set of properties or powers. But clearly, in the eighteenth century, there was a kind of ready-made Spinozism which seemed to be a philosophy tailor-made to the developments in the life sciences (Ibrahim 1990), whether or not it was fair to accuse, say, Boerhaave of Spinozism, or whether La Mettrie is a Spinozist in the restrictive sense defined by extensive acquaintance with Spinoza's system. Abbot Tandeau de Saint-Nicolas, writing against La Mettrie in 1745, presents Epicureanism and Spinozism as the two possible forms of the abhorrent vision called materialism: matter and mechanism producing animate bodies, or cosmic determinism and the eternity of the world; but curiously, he diagnoses La Mettrie as falling into the second category rather than the first. ${ }^{213}$ As noted earlier, Antoine-Martin Roche's 1759 critique of Locke and materialism makes a more apt distinction between two materialist views of the soul, a 'Spinozist' view (the soul is coextensive with the entire body), and a 'materialist' view (the soul is material per se). And Roche responds with a traditional invocation, both of the soul's indivisibility, and of its inherent 'inwardness' ("sentiment intérieur" 214), targeting Le Camus and other physicians who sought to articulate a 'medicine of the mind'.

211 Willis 1683, ch. VI, p. 33.

212 Priestley, Disquisitions Relating to Matter and Spirit (1777), in Priestley 1972, vol. 3, p. 230.

213 Tandeau de Saint-Nicolas 1745, pp. 15-16, 17.

${ }^{214}$ For Malebranche, too, we cannot have a clear idea of our soul, but only a "conscience ou sentiment intérieur" ("inner sensation," Malebranche 1674, 11 th Elucidation, in Malebranche 1997, p. 552); a phrase which can be explained thus: "The consciousness of one's existence, this inner sensation which constitutes the self, is composed in us of the sensation of our present existence and the memory of our past existence" (Buffon 1753, p. 51). But this can also be turned around into a statement of materialism, locating the soul in an integrated physiology or 'medicine of the mind'; even Lamy repeats that "the soul, which knows all things, does not know itself" (Lamy, Discours anatomiques, VI, in Lamy 1996, p. 95); there may be a limit to first-person knowledge! 
A question then is, what kind of materialism are we dealing with here? Clearly, the concept of matter at issue in these texts, at least from Gassendi and Willis onwards, is one which is heavily laden with chemical properties. Similarly, the specifically medical and thus embodied character of the soul appears with increasing force, from Boerhaave and Gaub to Ménuret and Diderot, with frequent invocations of Galen's provocative claim that the soul is just the "mixture of the body" (Galen 1997, pp. 153, 157). ${ }^{215}$ What may seem difficult to imagine for a reader of the post-Rylean era, is that a defence of a certain concept of soul is also an overt humoral reductionism, understood in a broad sense as a reduction to the substances of which the body is composed, its "mixture" but also its structure. But what conclusions can be drawn from this specificity? A methodological point concerning the history of philosophy and intellectual history, and a conceptual point concerning the very idea of the material soul.

Methodologically, the trajectory we have sought to describe indicates that there is a history, not just of materialist philosophies (Lucretius, Hobbes, Diderot, Priestley) but also of the presence of materialist 'components' or articulated wholes within philosophical systems that are not themselves materialistic: Descartes as appropriated by Regius, Malebranche as appropriated by L'âme matérielle, Spinoza and Bayle as appropriated by several generations of radical eighteenth-century thinkers - not to mention 'scientific' texts like those of Willis, Whytt or Haller, whose authors go out of their way to reject materialism, but who instantly become evidence for that view. ${ }^{216}$ This is not just a theoretical game (collage, appropriation, etc.), for as noted with respect to Malebranche's psychophysiology, sometimes the texts which were criticising a view could serve as the best evidential resource for an author who was not part of an inner sanctum of experimental natural philosophy. ${ }^{217}$

As to the material soul itself, it shows that the concept of soul is naturalised without being entirely eliminated: there is a productivity of the concept of material soul, once it becomes "wherever I read soul I replace it with man or animal." 218 This is an approach to body-soul or body-mind union

\footnotetext{
215 One of us discusses the 'embodied' aspect in more detail in Wolfe 2012a.

${ }^{216}$ For more discussion of the methodological niceties involved in approaching the history of materialism, see Bloch 1995; Aury and Wolfe 2008.

217 Thus Diderot in his writings on physiology can cite as evidence Robert Whytt's 'neuropneumatological' assertion that "the soul is equally present in the extremities of the nerves through the whole body as in the brain" (Whytt 1768, p. 287) even though Whytt had specified this was not tantamount to materialism, since these functions of the soul are themselves dependent on an "active sentient principle" which brought together sensibility and life, and could not be a property of matter itself (ibid., p. 128).

${ }^{218}$ Diderot, in Hemsterhuis / Diderot 1772/1964, p. 277.
} 
which is neither Cartesian nor Spinozist, neither squarely reductionist in a standard sense nor 'supervenient' or 'emergentist' in the sense of an insistence on the autonomy and/or ontological specificity of mental phenomena. That the soul is 'materialised' does not mean it is folded into a mechanistic ontology, 219 as would be the case in a materialist approach taken by "merchants of vanishing." Rather than be content with asserting a flattened-out ontology in which there are only masses of matter in motion, atoms, molecules, and other merely aggregative relations of piles of matter, shouldn't intelligent materialists - to borrow an expression from Deleuze 220 take up the challenge of conceptualising material souls?

\footnotetext{
219 Which also implies we are following a more 'Epicurean' than 'post-Cartesian' line, inasmuch as Vartanian's distinctions are applicable (although if we consider Malebranche's psychophysiology, or the multiple lines of fracture between Epicureanism and Spinozism suggested by interpreters of the period, the distinction loses its sharpness). For more on the chimiatric context of the material soul concept in Lamy et al. and how this distances the concept from mechanism, see Mothu 1990-1991, p. 390; on the implications of the Epicurean context, Wright 1991a; on La Mettrie's way of combining Epicurean and Cartesian elements, see Wolfe 2004.
}

220 Deleuze 1990, p. 257. 
References

Annas, Julia. 1992. Hellenistic Philosophy of Mind. Berkeley: University of California Press.

(Anon.). (approx. 1725-1730/2003). L'Âme Matérielle, ed. A. Niderst, 3d edition. Paris: Champion.

(Anon.). 1765/1966. "Physiologie." In Encyclopédie ou Dictionnaire raisonné des arts et des métiers, eds. Denis Diderot and Jean Le Rond D'Alembert, XII, 537538. Paris: Briasson, David, Le Breton \& Durand; reprint, Stuttgart/Bad Cannstatt: Frommann.

(Anon.). 1716/1768. Traité des trois imposteurs. Yverdon: De Felice.

(Anon.). 1716/1904. The Three Impostors, trans. Alcofribas Nasier (also the pseudonym of François Rabelais). Cleveland: n.p.

Argaud, Élodie. 2009. "Bayle's defence of Epicurus: The Use and Abuse of Malebranche's Méditations chrétiennes." In Neven Leddy \& Avi Lifschitz, eds., Epicurus in the Enlightenment, 69-83. Oxford: Voltaire Foundation.

Aucante, Vincent. 2006. La philosophie médicale de Descartes. Paris: PUF.

Aury, Mathieu and Wolfe, Charles T. 2008. "Sommes-nous les héritiers des

Lumières matérialistes?" Phares (Université de Laval) 8: 11-33

Bayle, Pierre. 1740. Dictionnaire historique et critique (1697), 4 vols., $5^{\text {th }}$ edition. Amsterdam-Leiden-The Hague: Pierre Brunel et al.

Bernier, François. 1678. Abregé de la philosophie de Mr. Gassendi, 8 vols. Lyon :

Anisson et Possuel.

Berkeley, George. 1999. Principles of Human Knowledge and Three Dialogues (1710), ed. Howard Robinson. Oxford: Oxford University Press.

Bitbol-Hespériès, Annie. 1990. Le principe de vie chez Descartes. Paris: Vrin. Bloch, Olivier. 1977. “Marx, Renouvier et l'histoire du matérialisme.” La Pensée 191: 3-42.

Bloch, Olivier. 1992. “L'héritage libertin dans la pensée des Lumières." Dixhuitième siècle 24: 73-82

Bloch, Olivier. 1995. Le matérialisme, 2nd edition. Paris: PUF, coll. “Que sais-je?" Bloch, Olivier. 2000. "La technique du collage dans la tradition libertine et clandestine." La Lettre clandestine 9: 127-142

Boerhaave, Herman. 1739. Praelectiones academicae in proprias institutiones rei medicae, ed. Albrecht von Haller, 3 vols. Göttingen: Anton Vandenhoeck. Bos, Jacques. 2009. "The rise and decline of character: humoral psychology in ancient and early modern medical theory." History of the Human Sciences 22(3): $29-50$ 
Boyle, Robert. 1772/1965. The Works of the Honourable Robert Boyle, 6 vols., ed. T. Birch. London: J. and F. Rivington et al.; reprint, Hildesheim: Georg Olms. Bright, Timothie. 1586. A Treatise of Melancholie: containing the causes thereof, and reasons of the strange effects it worketh in our minds and bodies, with the phisicke, cure, and spirituall consolation for such as have thereto adjoyned an afflicted conscience. London: Vautrollier.

Browne, Thomas. 1892. Religio Medici (1643), in Writings of Sir Thomas Browne, ed. D. Lloyd Roberts. London: David Stott.

Buffon, Georges-Louis-Leclerc de. 1753. Histoire naturelle, générale et particulière, vol. IV. Paris: Imprimerie Royale.

Burnham, William H. 1888. "Memory, Historically and Experimentally Considered." American Journal of Psychology 2: 39-90, 255-70, 431-64, 566-622 Burton, Robert. 1628. The Anatomy of Melancholy (first edition 1621). Oxford: John Lichfield.

Canguilhem, Georges. 1977. La formation du concept de réflexe, 2nd edition. Paris: J. Vrin.

Cardano, Girolamo. 1663/1966. In Hippocratis Coi Prognostica, in Charles Spon, ed., Opera omnia, 10 vols. Lyon: Huguetan and Rivaud; reprint, Stuttgart-Bad Cannstatt: Frommann.

Caron, Louis. 2011. The Philosophical Reception of Thomas Willis (1621-1675) with Particular Reference to John Locke (1632-1704). PhD Dissertation, Department of History, Cambridge University.

Charleton, Walter. 1659. The Immortality of the Human Soul, Demonstrated by the Light of Nature. In Two Dialogues. London: Herringman; facsimile reprint, New York: AMS Press.

Charleton, Walter. 1674. Natural History of the Passions. London: James Magnes.

Conry, Yvette. 1978. “Thomas Willis ou le premier discours rationaliste en pathologie mentale." Revue d'histoire des sciences 31(3): 193-231

Deleuze, Gilles. 1990. Spinoza and the Problem of Expression, trans. M. Joughin. New York: Zone Books.

Denesle. 1765. Les préjugés des anciens et nouveaux philosophes sur la nature de l'âme humaine, ou Examen du matérialisme, relativement à la métaphysique, 2 vols. Paris: Vincent et Dehansy.

Descartes, René. 1964-1974 . CEuvres, eds. C. Adam \& P. Tannery, 11 vols. Paris: Vrin (cited as AT followed by volume and page number)

Descartes, René. 1985. The Philosophical Writings of Descartes, eds. J. Cottingham, R. Stoothoff, D. Murdoch \& A. Kenny. Cambridge: Cambridge University Press (cited as CSMK followed by volume and page number) 
Des Chene, Dennis. 2000. Life's Form: Late Aristotelian Conceptions of the Soul. Ithaca: Cornell University Press.

D'Holbach, Paul Henri Dietrich. 1774. Le bon sens, ou Idées naturelles opposées aux idées surnaturelles. London: n.p. Available on Gallica at:

http://gallica.bnf.fr/ark:/12148/bpt6k739238

[Diderot, Denis.] 1765/1966. “Matérialistes (Théol.).”In Encyclopédie ou Dictionnaire raisonné des arts et des métiers, eds. Denis Diderot and Jean Le Rond D'Alembert, X, 718b. Paris: Briasson, David, Le Breton \& Durand; reprint, Stuttgart/Bad Cannstatt: Frommann.

Diderot, Denis. 1975-. CEuvres complètes, eds. H. Dieckmann, J. Proust \& J. Varloot. Paris: Hermann.

Digby, Sir Kenelm. 1645. Two Treatises in the one of which, the Nature of Bodies; in the other, the Nature of Man's Soule; is looked into: in Way of Discovery of the Immortality of Reasonable Soules. London: John Williams.

Dover Wilson, John. 1935. “Shakespeare's Knowledge of A Treatise of Melancholy by Timothy Bright." In Dover Wilson, What Happens in Hamlet, 309-320. Cambridge: Cambridge University Press

French, Roger K. 1969. Robert Whytt, The Soul and Medicine. London: Wellcome Institute.

Furetière, Antoine. 1702. Dictionnaire universel, contenant généralement tous les mots françois, tant vieux que modernes, $\mathcal{E}$ les termes de toutes les sciences et des arts. (1690), 2e édition, revue, corrigée et augmentée par Monsieur Basnage de Bauva. The Hague: Arnout \& Reinier Leers.

Galen. 1997. Selected Works, ed. \& trans. P.N. Singer. Oxford: Oxford University Press.

Garber, Dan. 1998. "Soul and Mind: Life and Thought in the Seventeenth Century." In The Cambridge History of Seventeenth-Century Philosophy, eds. D. Garber and M. Ayers, vol. 1, 759-795. Cambridge: Cambridge University Press.

Gassendi, Pierre. 1658. Opera omnia in sex tomos divisa, 6 vols., pref. Samuel Sorbière. Lyon: L. Anisson \& J.-B. Devenet.

Giglioni, Guido. 2008. "What ever happened to Francis Glisson? Albrecht Haller and the fate of eighteenth-century irritability." Science in Context 21(4): 465-493.

Hagner, Michael. 1992. "The soul and brain between anatomy and Naturphilosophie in the early nineteenth century." Medical History 36: 1-33. 
Haller, Albrecht von. 1774/1969. Bibliotheca anatomica qua scripta ad anatomen et physiologiam facientia a rerum initiis recensentur, Bd. I. Tiguri: apud Orell, Gessner, Fuessli et Socc. / Hildesheim: Olms Reprints.

Harvey, William. 1651/1981. Exercitationes De Generatione Animalium, trans. Gweneth Whitteridge. Oxford: Blackwell Scientific Publications.

Hatfield, Gary. 1995. "Remaking the Science of Mind: Psychology as Natural Science." In Inventing Human Science. Eighteenth-Century Domains, eds. C. Fox, R. Porter, R. Wokler, 184-231. Berkeley: University of California Press.

Hawkes, David. 2011. “Against Materialism in Literary Theory." Forthcoming in Early Modern Culture 9; online at http: / / emc.eserver.org/Hawkes.pdf.

Hemsterhuis, François. 1772/1964. Lettre sur l'homme et ses rapports, avec le commentaire inédit de Diderot, ed. G. May. New Haven: Yale University Press / Paris: PUF.

Henry, John. 1987. "Medicine and Pneumatology: Henry More, Richard Baxter, and Francis Glisson's Treatise on the Energetic Nature of Substance." Medical History 31: 15-40

Henry, John. 1989. “The Matter of Souls: Medical Theory and Theology in Seventeenth-Century England." In The Medical Revolution of the Seventeenth Century, eds. R.K. French and A. Wear, 87-113. Cambridge: Cambridge University Press.

Hill, Emita. 1968. "Materialism and Monsters in the Rêve de D'Alembert." Diderot Studies 10: 67-93

Hirai, Hiro. 2011. Medical Humanism and Natural Philosophy. Renaissance Debates on Matter, Life and the Soul. Leiden: Brill.

Huneman, Philippe. 2007. "'Animal Economy': Anthropology and the Rise of Psychiatry from the Encyclopédie to the Alienists." In The Anthropology of the Enlightenment, eds. Larry Wolff \& Marco Cipolloni, 262-276. Stanford:

Stanford University Press.

Iliffe, Rob. 1995. “'That Puzleing Problem': Isaac Newton and the Political Physiology of Self." Medical History 39: 433-458

Kolesnik, Delphine. 2011. “Comment rendre l'âme « comme matérielle » ? Le cas de Malebranche." Corpus 61: Matérialisme et cartésianisme, 201-215 Kors, Alan Charles. 1990. Atheism in France, 1650-1729. Princeton: Princeton University Press.

de La Forge, Louis. 1666. Traité de l'esprit de l'homme, de ses facultés et de ses fonctions, et de son union avec le corps. Suivant les principes de René Descartes. Paris: Théodore Girard.

Lagerlund, Henrik. 2004. "John Buridan and the Problems of Dualism in the Early Fourteenth Century." Journal of the History of Philosophy 42(4): 369-388 
Lalande, André. 1911. "Sur quelques textes de Bacon et de Descartes." Revue de Métaphysique et de Morale 3: 296-311

La Mettrie, Julien Offray de \& Boerhaave, Hermann. 1747. Institutions de médecine de M. Hermann Boerhaave, trans. with commentary by La Mettrie, $2^{\text {nd }}$ ed., vol. 5 out of 8. Paris: Huart \& Cie.

La Mettrie, Julien Offray de. 1751/1987. CEuvres philosophiques, ed. Francine Markovits, 2 vols. Paris: Fayard- "Corpus".

La Mettrie, Julien Offray de. 1960. L'Homme-Machine, edited and translated by Aram Vartanian. Princeton: Princeton University Press.

Lamy, Guillaume. 1996. Discours anatomiques. Explication méchanique et physique des fonctions de l'âme sensitive, ed. Anna Minerbi Belgrado. Paris:

Universitas / Oxford: Voltaire Foundation.

Le Camus, Antoine. 1753. Médecine de l'esprit, où l'on traite des dispositions et des causes physiques qui sont des conséquences de l'union de l'âme avec le corps, influant sur les opérations de l'esprit; et des moyens de maîtriser ses opérations dans un bon état ou de les corriger quand elles sont viciées. Paris: Ganeau.

Locke, John. 1975. Essay Concerning Human Understanding, ed. Peter Nidditch. Oxford: Oxford University Press.

LoLordo, Antonia. 2005. “Descartes and Malebranche on Thought, Sensation and the Nature of the Mind." Journal of the History of Philosophy 43(4): 387-402 Lucretius. 1692. Les œuvres de Lucrèce: contenant la philosophie sur la physique, où l'origine de toutes choses, trans. Jacques Parrain (Baron des Coutures). Paris: chez Thomas Guillain.

Malebranche, Nicolas. 1979. La Recherche de la Vérité, in CEuvres, ed. Geneviève Rodis-Lewis, vol. 1, Paris: Gallimard-Pléiade.

Malebranche, Nicolas. 1997. The Search After Truth (1674-1675), eds. Thomas M. Lennon and Paul J. Olscamp. Cambridge: Cambridge University Press.

Manning, Gideon. 2007. "Out on the Limb: The Place of Medicine in

Descartes' Philosophy." Review Essay, Early Science and Medicine 12: 214-222

Martin, Craig. forthcoming. "The Aristotelian Problemata and Late-

Renaissance Medical Philosophy." In Medicine and Early Modern Natural

Philosophy, eds. Benjamin Goldberg, Peter Distelzweig, and Evan Ragland.

Dordrecht: Springer.

Maupertuis, Pierre-Louis Moreau de. 1768/1967. CEuvres, 4 vols. Lyon: J.-M.

Bruyset; reprint, ed. G. Tonelli, Hildesheim: Georg Olms.

Ménuret de Chambaud, Jean-Joseph. 1765/1966. "Mort (Médecine)."

In Encyclopédie ou Dictionnaire raisonné des arts et des métiers, eds. Denis Diderot 
and Jean Le Rond D'Alembert, X, 718-727. Paris: Briasson, David, Le Breton \& Durand; reprint, Stuttgart/Bad Cannstatt: Frommann.

Mori, Gianluca and Mothu, Alain. 2003. 'L'Âme matérielle'; 'De la conduite qu'un honnête homme doit garder pendant sa vie'; 'Préface du traité sur la religion de M.***': trois manuscrits, un seul auteur?." La Lettre clandestine 12: 311-339 Mothu, Alain. 1990-1991. "La pensée en cornue: considérations sur le matérialisme et la 'chymie' en France à la fin de l'âge classique." Chrysopoeia 4: 307-445

Paganini, Gianni. 1985. “L'anthropologie naturaliste d'un esprit fort. Thèmes et problèmes pomponaciens dans le Theophrastus redivivus." XVIIe siècle 149: 349-377

Pagel, Walter. 1967. Harvey's Biological Ideas. New York: Hafner.

Park, Katharine. 1988. "The Organic Soul." In The Cambridge History of

Renaissance Philosophy, eds. Charles B. Schmitt and Quentin Skinner, 464-484.

Cambridge: Cambridge University Press.

Petrescu, Lucian. ms. 2012. “Descartes on the heartbeat: the Leuven controversy."

Pluquet, François-André-Adrien, Abbé. 1788. Mémoires pour servir à l'histoire des égarements de l'esprit humain par rapport à la religion chrétienne : ou Dictionnaire des hérésies, des erreurs et des schismes (1762). Sedan: Charles Morin.

Priestley, Joseph. 1778. A Free Discussion of the Doctrines of Materialism and Philosophical Necessity in a Correspondence between Dr. Price and Dr. Priestley. London: Johnson \& Cadell.

Priestley, Joseph. 1972. The Theological and Miscellaneous Works of Joseph Priestley. New York: Kraus Reprint Company.

Rapp, Christof. 2006. "Interaction of Body and Soul: What the Hellenistic Philosophers Saw and Aristotle Avoided." In Common to Body and Soul: philosophical approaches to explaining living behaviour in Greco-Roman antiquity, ed. R.A.H. King, 187-208. Berlin: Walter de Gruyter.

Rather, L.J. 1965. Mind and Body in Eighteenth-Century Medicine. A Study Based on J. Gaub's De regimine mentis. Berkeley: University of California Press.

Regius, Henricus. 1646. Fundamenta physices. Amsterdam: Elzevier.

Rey, Roselyne. 2000. "Diderot and the Medicine of the Mind." In The Renewal of Materialism, ed. C.T. Wolfe, Graduate Faculty Philosophy Journal 22(1): 149-159 Schmaltz, Tad M. 1994. "Malebranche on Descartes on Mind-Body Distinctness." Journal of the History of Philosophy 32(4): 573-603 Siraisi, Nancy G. 1997. The Clock and the Mirror. Girolamo Cardano and Renaissance Medicine. Princeton: Princeton University Press. 
Smith, Lisa Wynne . 2008. "'An Account of an Unaccountable Distemper': The Experience of Pain in Early Eighteenth-Century England and France." Eighteenth-Century Studies 41(4): 459-480

Soemmerring, Samuel Thomas. 1796. Über das Organ der Seele. Königsberg: Friedrich Nicolovius.

Star, Susan Leigh and Griesemer, James R. 1989. “Institutional Ecology, 'Translations', and Boundary Objects: Amateurs and Professionals in Berkeley's Museum of Vertebrate Zoology, 1907 - 1939." Social Studies of Science 19: 387-420

Sutton, John. 1998. Philosophy and Memory Traces. Cambridge: Cambridge University Press.

Sutton, John. Forthcoming. "Body and Soul in Seventeenth-Century British Philosophy." In The Oxford Handbook of British Philosophy in the Seventeenth Century, ed. Peter Anstey. Oxford: Oxford University Press.

Sutton, John. and Tribble, Evelyn B. forthcoming. "Materialists are not merchants of vanishing. Commentary on David Hawkes, 'Against Materialism in Literary Theory'." Early Modern Culture 9

Tabb, Kathryn. forthcoming. "'Struck, As It Were, With Madness': The Phenomenology of Animal Spirits in the Neurology of Thomas Willis." In Brain and Mind: Essays on the history of neuroscience, eds. C.U.M. Smith and H.A. Whitaker. Dordrecht: Springer.

Tandeau de Saint-Nicolas, François-Bruno. 1745. Lettre de Monsieur ${ }^{* * *}$ Maître en chirurgie a $M .{ }^{* * *}$ Médecin sur le livre intitulé Histoire Naturelle de l'Âme [s.l.: s.n.]

Thomson, Ann. 2001."Materialistic theories of mind and brain." In Between Leibnitz, Newton and Kant: Philosophy and Science in the Eighteenth century, ed. Wolfgang Lefèvre, 149-173. Dordrecht: Kluwer.

Thomson, Ann. 2006. “Encore l'âme matérielle." La Lettre clandestine 14: 55-70 Thomson, Ann. 2008. Bodies of Thought: Science, Religion, and the Soul in the Early Enlightenment. Oxford: Oxford University Press.

Trevor, Douglas. 2004. The Poetics of Melancholy in Early Modern England. Cambridge: Cambridge University Press. van der Eijk, Philip. 2005. Medicine and Philosophy in Classical Antiquity. Cambridge: Cambridge University Press. Vartanian, Aram. 1982. "Quelques réflexions sur le concept d'âme dans la littérature clandestine." In Le matérialisme du XVIII e siècle et la littérature clandestine, ed. Olivier Bloch, 149-165. Paris: Vrin.

Whytt, Robert. 1768. The Works of Robert Whytt, M.D., published by his son. Edinburgh: J. Balfour. 
Willis, Thomas. 1659/1681. De fermentatione, translated as A MedicalPhilosophical Discourse of Fermentation; or, Of the Intestine Motion of Particles in Every Body by S. Pordage. London: Dring, Harper, Leigh, and Martin. Willis, Thomas. 1683. Two Discourses Concerning the Soul of Brutes, Which is That of the Vital and Sensitive [Soul] of Man. The first is physiological, shewing the nature, parts, powers, and affections of the same. The other is pathological, which unfolds the diseases which affect it, a translation of De anima brutorum (1672), Englished by S. Pordage. London: Dring, Harper and Leigh.

Willis, Thomas. 1684. An Essay of the Pathology of the Brain and Nervous Stock: In Which Convulsive Diseases are Treated of (translation of De Morbis Convulsivis), in Dr. Willis's Practice of Physick, trans. S. Pordage. London: T. Dring, C. Harper \& J. Leigh.

Wolfe, Charles T. 1999. “Machine et organisme chez Diderot." Recherches sur Diderot et l'Encyclopédie 26: 213-231

Wolfe, Charles T. 2004. "'Epicuro-Cartesianism': La Mettrie's Materialist Transformation of Early Modern Philosophy." In La Mettrie. Ansichten und Einsichten, ed. Hartmut Hecht, 75-95. Berlin: Berlin Wissenschafts-Verlag. Wolfe, Charles T. 2009. "A happiness fit for organic bodies: La Mettrie's medical Epicureanism." In Epicurus in the Enlightenment, eds. Neven Leddy \& Avi Lifschitz, 69-83. Oxford: Voltaire Foundation.

Wolfe, Charles T. 2010. "Conditions de la naturalisation de l'esprit: la réponse clandestine." La Lettre clandestine 18: 54-88

Wolfe, Charles T. 2012a. "Forms of Materialist Embodiment." In Anatomy and the Organisation of Knowledge, 1500-1850, eds. Matthew Landers \& Brian Muñoz, 129-144. London: Pickering and Chatto.

Wolfe, Charles T. 2012b. “Le mécanique face au vivant." In L'automate: modèle, machine, merveille, eds. B. Roukhomovsky, S. Roux et al., 115-138. Bordeaux: Presses universitaires de Bordeaux.

Wolfe, Charles T. forthcoming 2012. "Teleomechanism redux? The conceptual hybridity of living machines in early modern natural philosophy." Gesnerus, special issue: Entre mécanisme et téléologie: Anatomie, physiologie et philosophie des fonctions, XVI ${ }^{e}-X V I I I{ }^{e}$ siècles.

Wolfe, Charles T. forthcoming 2013. "Sensibility as vital force or as property of matter in mid-eighteenth-century debates." In Sensibilité: The Knowing Body in the Enlightenment, ed. Henry Martyn Lloyd. Dordrecht: Springer.

Wright, John P. 1991a. "Locke, Willis, and the Seventeenth-Century Epicurean Soul." In Atoms, Pneuma, and Tranquillity: Epicurean and Stoic Themes in European Thought, ed. Margaret J. Osler, 239-258. Cambridge: Cambridge University Press. 
Wright, John P. 1991b. “The embodied soul in seventeenth-century French medicine." Canadian Bulletin of the History of Medicine 8: 21-42.

Wright, John P. 2000. "Substance vs. Function Dualism in Eighteenth-Century Medicine." In Psyche and Soma. Physicians and Metaphysicians on the Mind-Body Problem from Antiquity to the Enlightenment, eds. John P. Wright \& Peter Potter, 237-254. Oxford: Clarendon Press.

Yolton, John W. 1983. Thinking Matter: Materialism in Eighteenth-Century

Britain. Oxford: Basil Blackwell.

Yolton, John W. 1987. “French Materialist Disciples of Locke." Journal of the History of Philosophy 25: 83-104.

Yvon, Abbé Claude. 1765. "Immatérialisme ou Spiritualité (Métaph.)."

In Encyclopédie ou Dictionnaire raisonné des arts et des métiers, eds. Denis Diderot and Jean Le Rond D'Alembert, VIII, 570-574. Paris: Briasson, David, Le Breton \& Durand; reprint, Stuttgart/Bad Cannstatt: Frommann. 